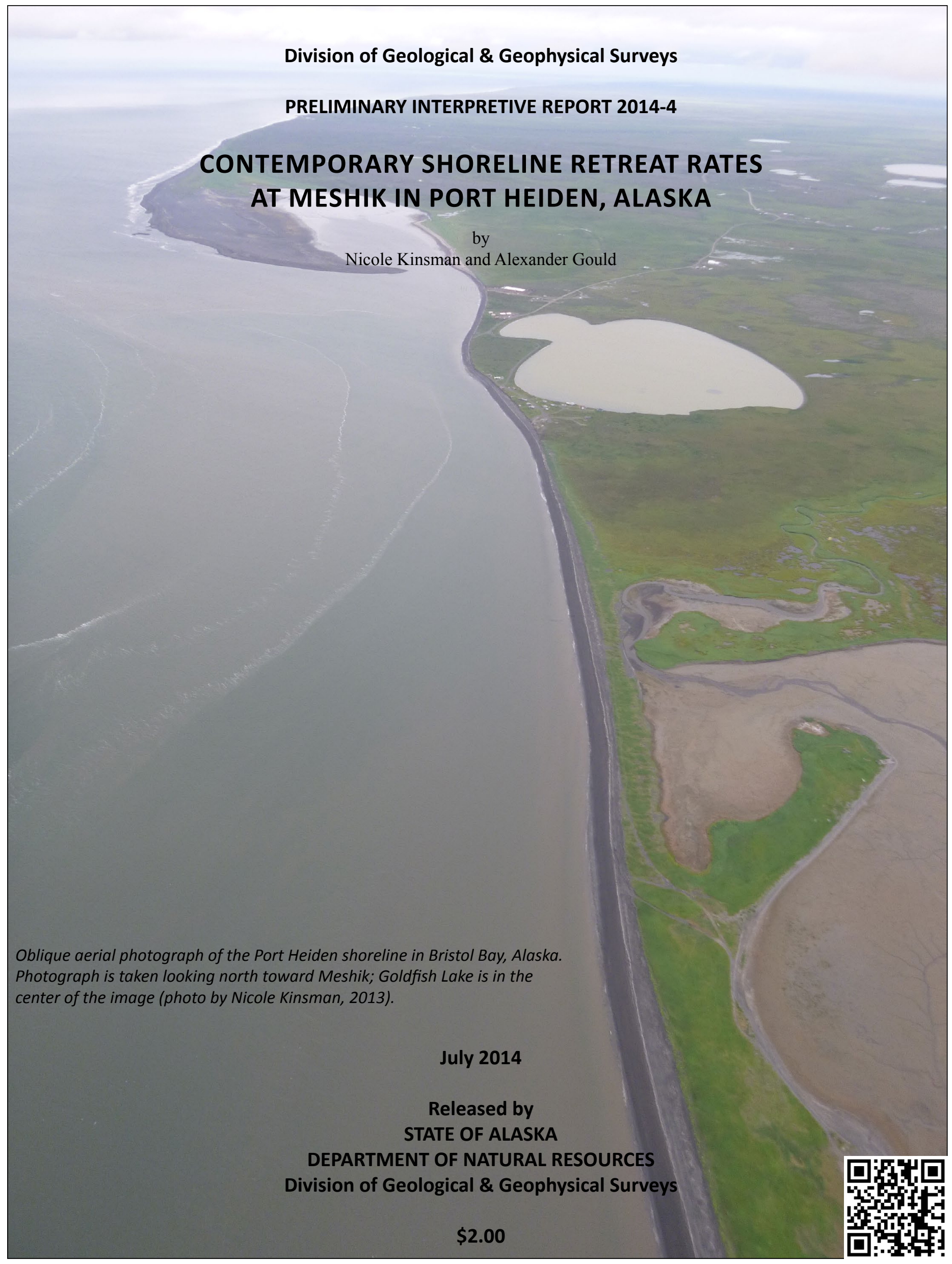



This work is funded with qualified outer continental shelf oil and gas revenues through the Coastal Impact Assistance Program, U.S. Fish and Wildlife Service, U.S. Department of the Interior. The views and conclusions contained in this document are those of the authors and should not be interpreted as representing the opinions or policies of the U.S. Government. Mention of trade names or commercial products does not constitute their endorsement by the U.S. Government.

\section{CONTENTS}

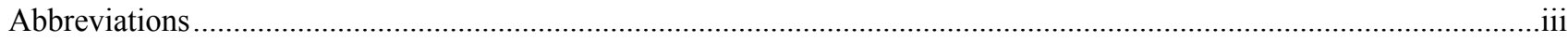

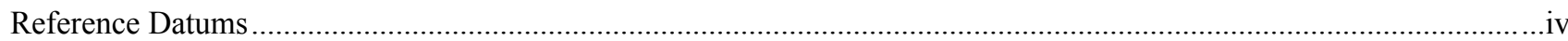

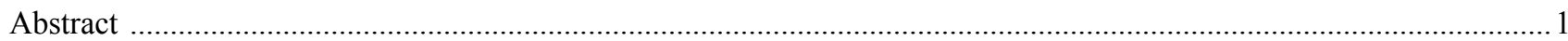

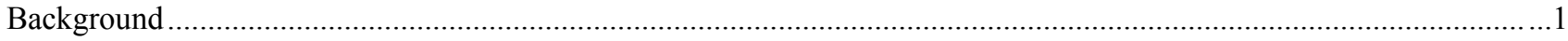

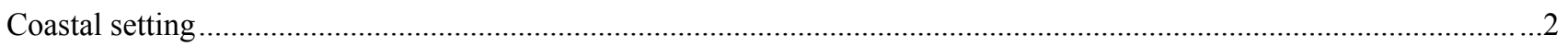

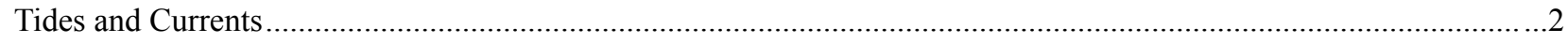

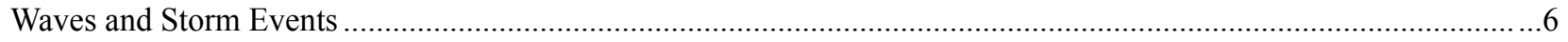

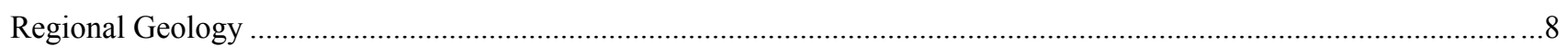

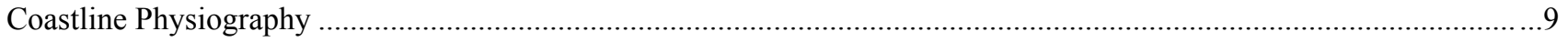

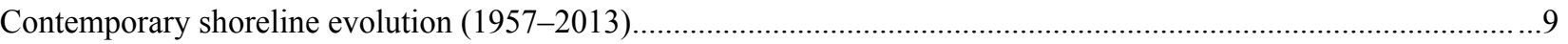

Method for Calculating Shoreline Retreat Rates .............................................................................................

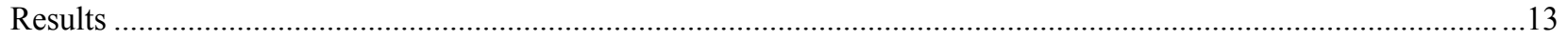

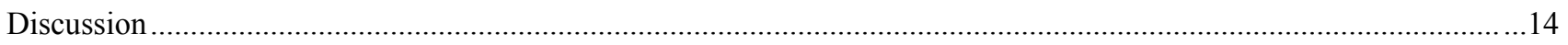

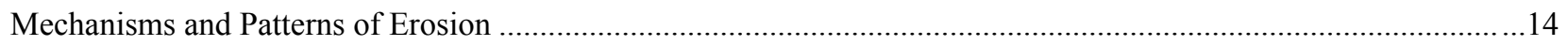

Coastline and Landform Modification...............................................................................................................

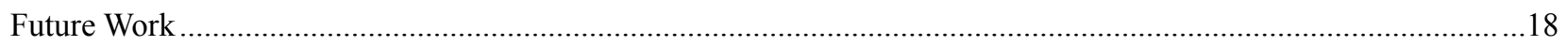

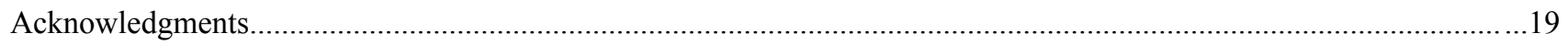

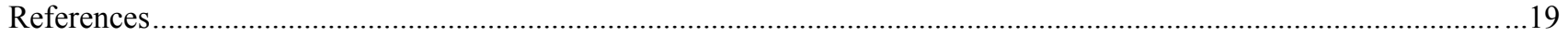

\section{FIGURES}

Figure 1. Locations of Port Heiden and the Meshik shoreline study area shown on a 2000 compilation

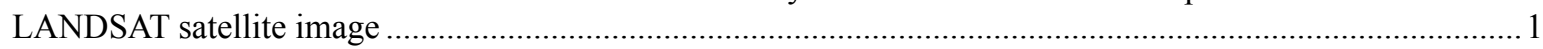

2. Map of Meshik study area, illustrating the locations of coastal elevation transects measured in August 2013

3. Repeat oblique aerial photographs of the Meshik coastline in 2006 and 2013 ............................................. 4

4. Graphic representation of the relative strength of component marine energy in Bristol Bay, and the

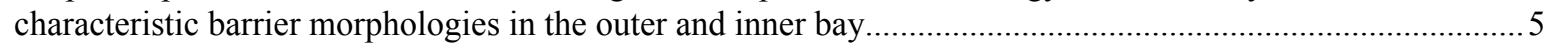

5. Comparison of the 1957 and 2013 tidal datums for Port Heiden, aligned through a common benchmark (Meshik-1949) of known elevation .......................................................................................... 6

6. Photographs taken in Meshik of the low-lying barrier spit to the south and the bluffs at the site during storms in 2005 under both ice-free conditions and in the presence of shore ice .............................................. 7

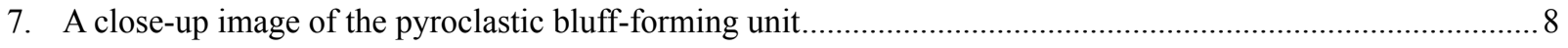

8. Plots of repeat coastal elevation profiles at the Barge Landing and Tank Farm transects ................................ 11

9. Plots of repeat coastal elevation profiles at the Fuel Header and 'South of Meshik' transects .........................12

10. Viable shoreline proxy positions at each virtual transect position from north to south in the study area, and alongshore rates of long-term shoreline change 
11. Position of the shoreline through the entire time series relative to the position in 1957 at three representative transects

12. Long-term shoreline change rates for the entire study area, presented as a graphical band along the coast

13. Fuel header pipes for Port Heiden's bulk fuel farm undercut by the eroding bluff during the 2013 storm season

14. Photographs of the Meshik bluffs both during and immediately after a December 2007 storm, showing undercutting at the base of the bluff from direct wave impact

15. Diagrammatic series of shorelines in and around the Meshik study area from 1957, 1973, 1983, and 2011 that illustrate the reworking of the barrier system

\section{TABLES}

Table 1. Summary of all known documented reports of absolute shoreline retreat or shoreline retreat rates at the Meshik site. Original source language is provided, along with conversion into consistent metric values for comparison.

2. List of the eight temporal shoreline vectors, the image sources and dates, and the combined horizontal uncertainty associated with each proxy shoreline position $\left(U_{t}\right)$ 


\section{ABBREVIATIONS}

\begin{tabular}{|c|c|}
\hline ACMP & Alaska Coastal Management Program \\
\hline AkCCO & Alaska Corps of Coastal Observers \\
\hline ANTHC & Alaska Native Tribal Health Consortium \\
\hline DCRA & Division of Community and Rural Affairs \\
\hline DGGS & Division of Geological \& Geophysical Surveys \\
\hline DSAS & Digital Shoreline Analysis System \\
\hline FUDS & Formerly Used Defense Sites \\
\hline GIS & Geographic Information System \\
\hline GNSS & Global Navigation Satellite System \\
\hline GPS & Global Positioning System \\
\hline HSIA & Historical Sea Ice Atlas \\
\hline MHHW & Mean Higher High Water \\
\hline MHW & Mean High Water \\
\hline MLLW & Mean Lower Low Water \\
\hline MSL & Mean Sea Level \\
\hline NAVD88 & North American Vertical Datum of 1988 \\
\hline NGS & National Geodetic Survey \\
\hline NAD83 & North American Datum of 1983 \\
\hline NTDE & National Tidal Datum Epoch \\
\hline NOAA & National Oceanic and Atmospheric Administration \\
\hline PDO & Pacific Decadal Oscillation \\
\hline PID & Position Identifier \\
\hline RMS & Root Mean Squared \\
\hline SLRG & Sea Level Research Group \\
\hline USACE & United States Army Corps of Engineers \\
\hline
\end{tabular}




\section{REFERENCE DATUMS}

Both horizontal and vertical coordinate information are referenced to NAD83(2011)(EPOCH:2010).

Vertical coordinate information is in orthometric heights, referenced to NAVD88(GEOID12A). Due to errors in the NGS GEOID12A for parts of Alaska, orthometric heights obtained using GEOID12A may differ from NAVD88 elevations obtained through local geodetic leveling.

The local offset between the geodetic and tidal datums incorporates the published orthometric height of the primary tidal benchmark (4075 B 2013) and unpublished local tidal station datum elevations calculated for the 1983-2001 National Tidal Datum Epoch:

\begin{tabular}{|c|c|c|c|c|c|}
\hline \multirow{2}{*}{$\begin{array}{c}\text { Location } \\
\text { Name }\end{array}$} & \multirow{2}{*}{$\begin{array}{c}\text { Tide } \\
\text { Station } \\
\text { ID }\end{array}$} & $\begin{array}{c}\text { Tidal datum } \\
\text { analysis period }\end{array}$ & \multicolumn{2}{|c|}{$\begin{array}{c}\text { Benchmark used for vertical } \\
\text { control }\end{array}$} & $\begin{array}{c}\text { NAVD88 } \\
\text { orthometric } \\
\text { height } \\
\text { source }\end{array}$ \\
\hline Meshik & 9464075 & $10 / 11-11 / 11 / 2013$ & Stamping & $\begin{array}{c}\text { NGS Position ID } \\
\text { (PID) }\end{array}$ & \\
\hline
\end{tabular}

The following tidal datum conversions are presented as a convenience; they are subject to change and may vary in subsequent tidal epochs:

\begin{tabular}{lll} 
Add/Subtract & from & To obtain \\
\hline$+0.906 \mathrm{~m}$ & NAVD88 & Elevation above local MLLW in Port Heiden \\
$-1.055 \mathrm{~m}$ & NAVD88 & Elevation above local MSL in Port Heiden \\
$-2.283 \mathrm{~m}$ & NAVD88 & Elevation above local MHW in Port Heiden \\
$-2.640 \mathrm{~m}$ & NAVD88 & Elevation above local MHHW in Port Heiden \\
\hline
\end{tabular}




\title{
CONTEMPORARY SHORELINE RETREAT RATES AT MESHIK IN PORT HEIDEN, ALASKA
}

by

Nicole Kinsman ${ }^{1}$ and Alexander Gould ${ }^{1}$

\begin{abstract}
Bluff erosion has been a recurring hazard to the Meshik shoreline, and beginning in 1981 the geographic population center of Port Heiden began to migrate inland. This report summarizes the best available data for the assessment of shoreline change at Meshik. We present bluff retreat rates based on a 56-year time series of orthorectified aerial imagery and provide possible explanations for the observed alongshore variation based on the geomorphic evolution of this coast. Analysis of a $3.8 \mathrm{~km}$ segment of coastline revealed long-term erosion rates that range from stable to $7.3 \pm 1.8 \mathrm{~m} / \mathrm{yr}$. Recent biennial shoreline retreat is occurring at rates in excess of $13 \mathrm{~m} / \mathrm{yr}$ near some of the critical infrastructure. The natural reconfiguration of the barrier island into an attached spit, under stable relative sea level conditions, suggests a shift in the relative strength of various types of marine energy at this coast, indicative of increased wave and storm activity.
\end{abstract}

\section{BACKGROUND}

Port Heiden is an incorporated city of 102 residents (U.S. Census 2010) in the Lake and Peninsula Borough. The community is on the Bristol Bay side of the Alaska Peninsula, at the north entrance of the Port Heiden embayment and $25 \mathrm{~km}$ west of Aniakchak volcano (fig. 1). During World War II, more than 2,000 personnel were stationed at Port Heiden's Fort Morrow Air Force Station, and gun emplacements, foxholes, slit trenches, and barbed-wire entanglements lined the local beaches (Stergiou, 2013). Coastal land in the region is currently under state, tribal, and municipal management. An Alaska Critical Habitat Area, established in 1972, encompasses the southern shoreline of the Port Heiden embayment (Alaska Coastal Management Program [ACMP], 2007).

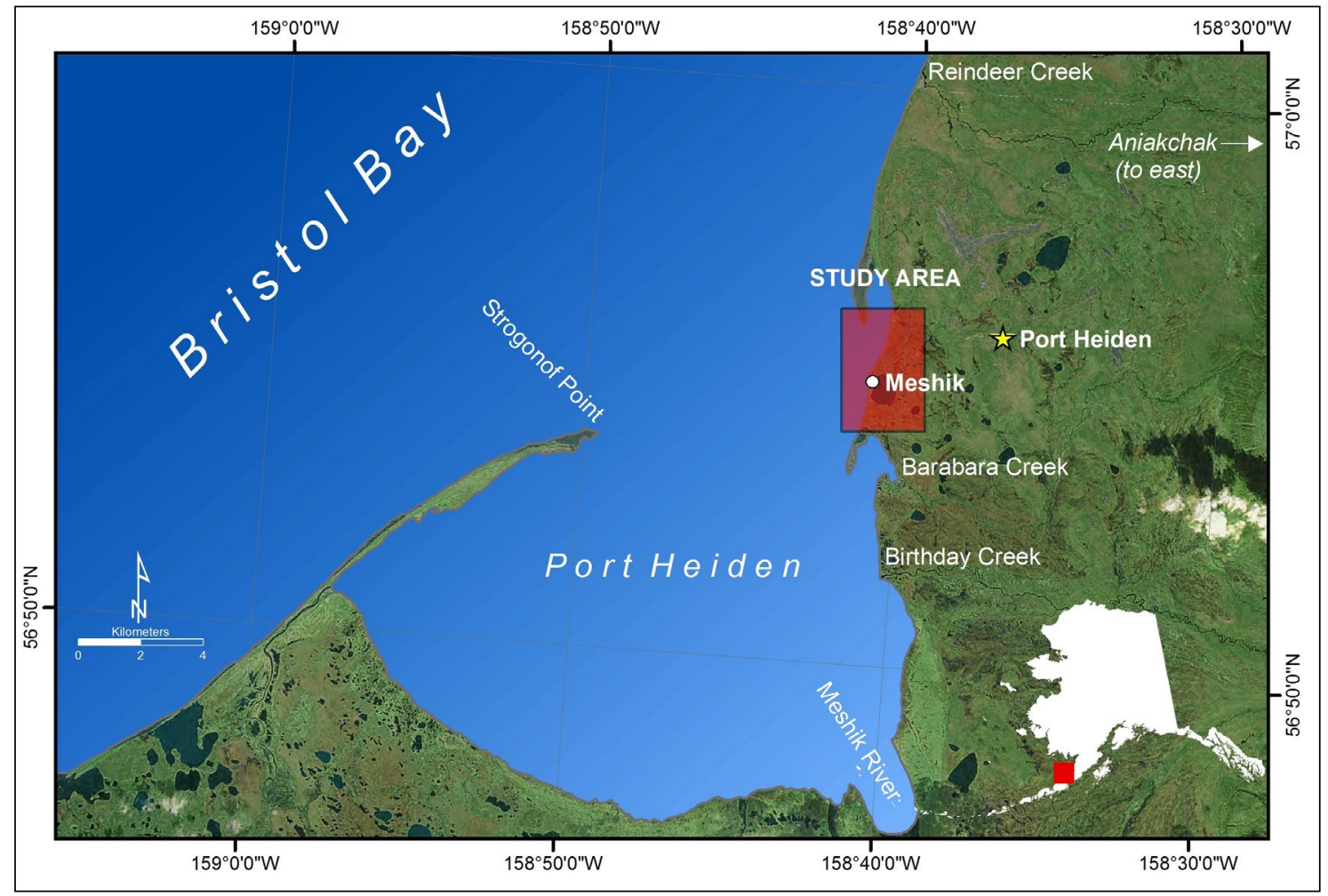

Figure 1. Locations of Port Heiden and the Meshik shoreline study area (outlined in red) shown on a 2000 compilation LANDSAT satellite image.

${ }^{1}$ Alaska Division of Geological \& Geophysical Surveys, 3354 College Rd., Fairbanks, Alaska 99709-3707; nicole.kinsman@alaska.gov and alexander.gould@alaska.gov 
Meshik, the focus of this report, is a historical coastal village site $4 \mathrm{~km}$ southwest of Port Heiden (fig. 2). The developed area lies on the eastern edge of the Port Heiden embayment, adjacent to Goldfish Lake. The location was initially abandoned in the early 1900s following an influenza epidemic. After World War II and the establishment of Fort Morrow, a new school was built and the population rebounded. Gradually, beginning in 1981, many city buildings were moved inland in response to ongoing coastal erosion, and private residences have eventually relocated inland as well (Division of Community and Regional Affairs [DCRA], 2014).

The proximity of Meshik and World War II-era Formerly Used Defense Sites (FUDS) to the eroding coastline has left Port Heiden with a legacy of required clean-up efforts to mitigate environmental impacts. A 1.3 acre landfill on the north side of Meshik, which contained both municipal and military waste, was operational from approximately 1940 until 2010 and had largely eroded into the ocean by early 2013 (Stergiou, 2013). Noteworthy remediation or relocation efforts in the last 30 years include the demolition of the White Alice communications station and associated nearby fuel tanks in the early 1990s, a drum removal project by the U.S. Army Corps of Engineers (USACE) in 2007, and the relocation of at least two gravesites and a 19th century Russian Orthodox church (Iliaska Environmental, 2008; National Oceanic and Atmospheric Administration [NOAA], 2007; Legare, 2000).

A rapidly retreating coast at the Meshik site continues to impact Port Heiden (fig. 3). Approximately two dozen vacant and deteriorating structures and associated debris remain at Meshik and a 2008 environmental report recognized the site as having unknown volumes of potentially hazardous materials present in the debris that could present a risk to human health and the environment (Iliaska Environmental, 2008). Additionally, critical Port Heiden city resources remain at Meshik today. These include the fuel header, fuel storage tanks, barge landing site, and road access to the primary boat haul-out area to the south. Two above-ground fuel storage tanks were moved from an eroding marine terminal area in 1982. A new tank farm with new storage tanks, a pump house, and distribution pipes was constructed in 2002 (Iliaska Environmental, 2008). In fall 2013, the old storage tanks had to be relocated farther inland once again (Scott Anderson, 2013, oral commun.).

\section{COASTAL SETTING}

\section{Tides and Currents}

In Bristol Bay, the tidal range increases from the mouth $(\sim 2 \mathrm{~m})$ to the head $(>5 \mathrm{~m})$ of the bay, and local variations are heavily influenced by seasonal and interannual variability in the currents (fig. 4; Wise and others, 1987). Port Heiden, situated at the juncture between the inner and outer parts of Bristol Bay, experiences a mixed semidiurnal tide with a great diurnal range of $3.5 \mathrm{~m}$. A historic tidal datum was established for Port Heiden in 1957 based on water-level measurements from August 9-30 of that year. The original primary tidal benchmark for this datum (BM1-1957) has no known geodetic height; it was located on Chistiakof Island (no longer in existence) and was destroyed less than a decade after installation.

In fall 2013, DGGS oversaw the establishment of new local tidal datum values using a qualified subcontractor. The re-established tertiary tide station was operational from September 11 through October 11, 2013, and new datums were calculated for the 1983-2001 NTDE using one month of water-level data combined with simultaneous water-level values from the Port Moller control tide station. These new values are tied to a primary tidal benchmark (946 4075 B) with a known geodetic height, which allows for offset computations between tidal datums and NAVD88 (table 1).

To assess trends in the position of relative sea level at Port Heiden, we used the best available data to align the superseded datum values with the new measured values (fig. 5). For this region the only benchmark with tide-coordinated geodetic heights for both 1957 and 2013 is 'Meshik-1949' (PID UW1437) near Goldfish Lake. Alignment of the two datums using this common benchmark suggests that the relative sea level has remained stable during this time period. This is corroborated by preliminary measurements of insignificant vertical land movement (observed rates of change from 1994 to 2014 are less than the measurement uncertainties of $\pm 0.3 \mathrm{~mm} /$ year; oral commun., Kimberly Tweet, 2014) and a minimal local sea surface trend of approximately -1 to $0 \mathrm{~mm} /$ year in central Bristol Bay (1993-2012 rate derived from satellite altimetry; Sea Level Research Group [SLRG], 2013).

Circulation in Bristol Bay is driven by winds, tides, and thermohaline gradients created by freshwater runoff that flows into the Bay. An incomplete gyre (some flow exits into the Arctic Ocean) proceeds counterclockwise in outer Bristol Bay and flows northward near Port Heiden, where the gyre mixes with the brackish water of the inner Bay (Wise and others, 1987). Longshore coastal currents on the north edge of the Alaska Peninsula flow toward the northeast at rates of $1-6 \mathrm{~cm} / \mathrm{sec}$ (Schumacher and Kinder, 1983). These coastal currents flow within $50 \mathrm{~km}$ of the shore and are largely baroclinic (densitybased) and tidally driven (Wise and others, 1981).

\section{Waves and Storm Events}

On a regional scale, significant wave heights decrease from the mouth of Bristol Bay toward the head (fig. 4). In this part of Bristol Bay winds prevail from the northwest, with stronger and more northerly winds occurring in the late fall to 


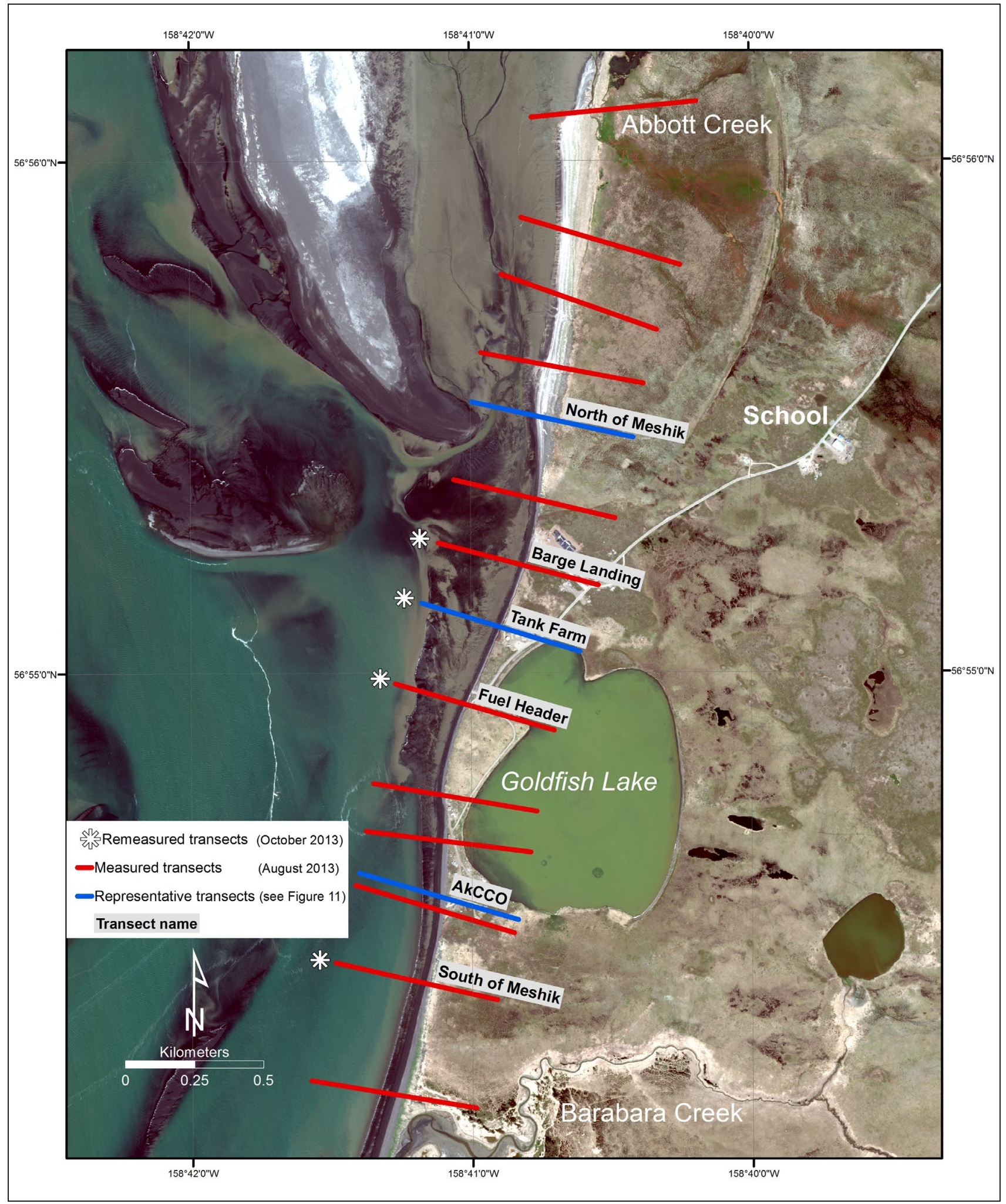

Figure 2. Map of Meshik study area, illustrating the locations of coastal elevation transects (red and blue) measured in August 2013. Profiles with asterisks $\left({ }^{*}\right)$ were remeasured in October 2013, partially into the storm season; these measurements are plotted in figures 8 and 9 . Blue indicates representative transects that exhibit typical alongshore variation in the shoreline change rates; detailed plots of these rates are shown in figure 11. The base map is a Worldview-2 satellite image taken June $17,2013$. 


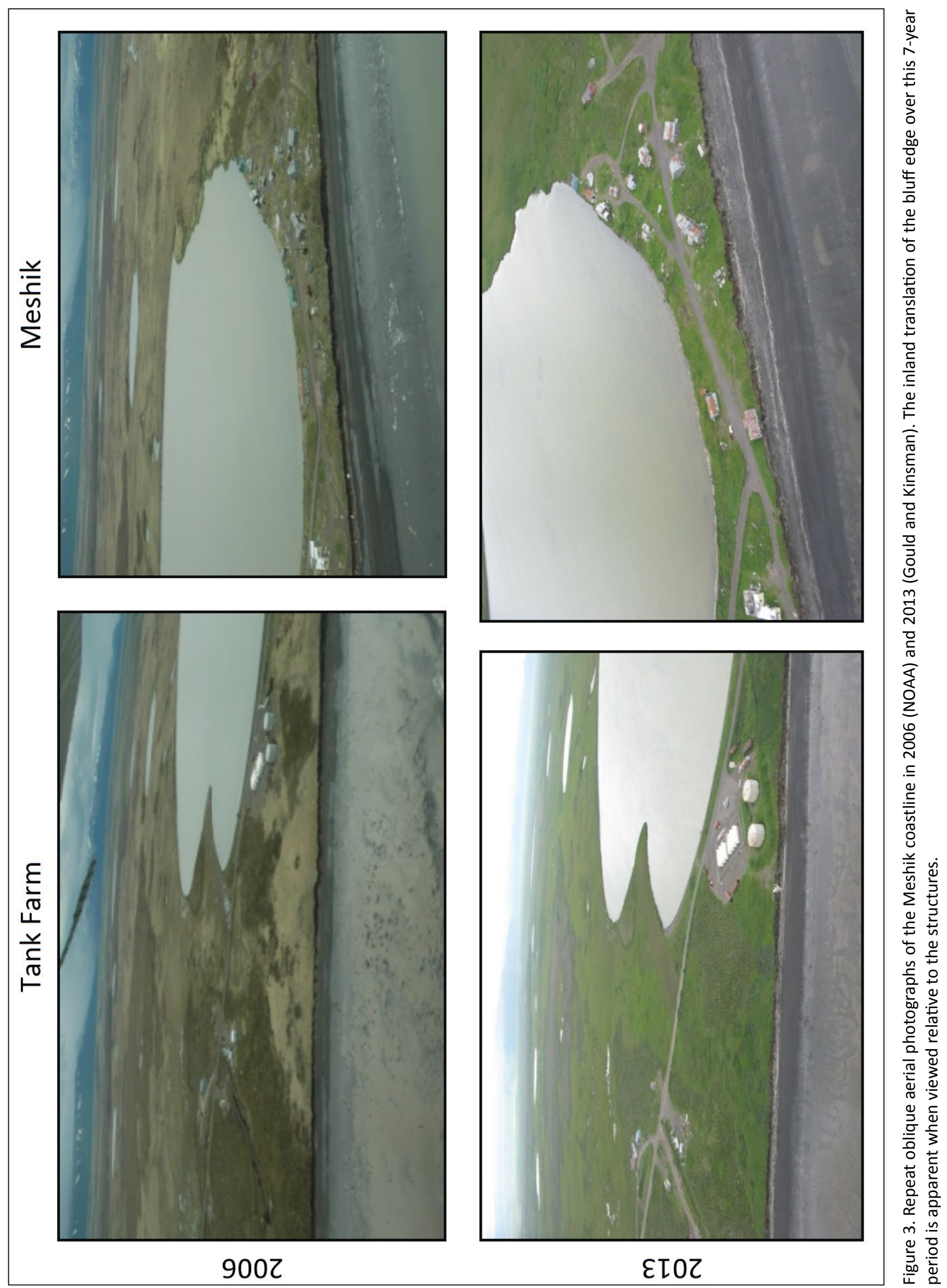




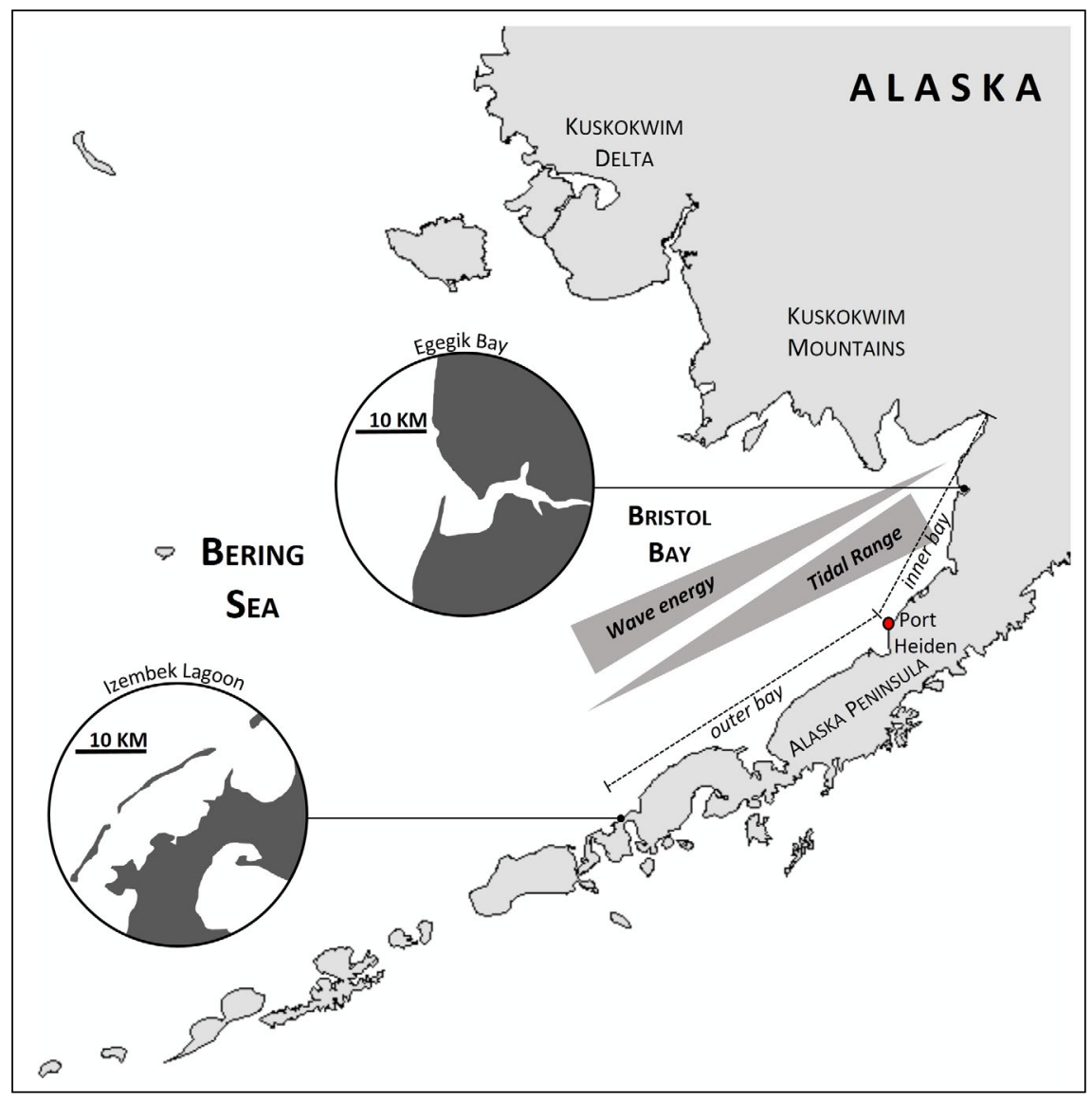

Figure 4. Graphic representation of the relative strength of component marine energy (tide and wave) in Bristol Bay, and the characteristic barrier morphologies in the outer (well-developed barrier islands, such as Izembek Lagoon) and inner bay (barrier spits at embayment mouths, such as Egegik Bay).

Table 1. Summary of all known documented reports of absolute shoreline retreat or shoreline retreat rates at the Meshik site. Original source language is provided, along with conversion into consistent metric values for comparison.

\begin{tabular}{|l|c|c|c|c|}
\hline \multicolumn{1}{|c|}{ Quote } & Source & $\begin{array}{c}\text { Retreat } \\
\text { (in } \mathrm{m} \text { ) }\end{array}$ & $\begin{array}{c}\text { Time } \\
\text { Period }\end{array}$ & $\begin{array}{c}\text { Estimated } \\
\text { Rate (m/y) }\end{array}$ \\
\hline $\begin{array}{l}\text { "In the fall of 1974, approximately 20 feet of bank } \\
\text { was eroded with resultant property damage" }\end{array}$ & $\begin{array}{c}\text { Kvasager, } \\
1975\end{array}$ & 6 & 1974 & 6 \\
\hline $\begin{array}{l}\text { "beach erosion, one damaged house, one evacuated } \\
\text { home" }\end{array}$ & $\begin{array}{c}\text { Wise and } \\
\text { others, 1981 }\end{array}$ & - & $\begin{array}{c}\text { Oct 27- } \\
28,1976\end{array}$ & - \\
\hline $\begin{array}{l}\text { "Barges temporarily beached near Port Heiden. } \\
\text { Reported damages to the greater region totaling } \\
\text { around \$500,000" }\end{array}$ & $\begin{array}{c}\text { Wise and } \\
\text { others, 1981 }\end{array}$ & - & $\begin{array}{c}\text { Oct 25- } \\
26,1977\end{array}$ & - \\
\hline $\begin{array}{l}\text { "Port Heiden boats and homes damaged. Max surge } \\
\text { in the region was 11 ft" }\end{array}$ & $\begin{array}{c}\text { Wise and } \\
\text { others, 1981 }\end{array}$ & - & $\begin{array}{c}\text { August } \\
17-18, \\
1980\end{array}$ & - \\
\hline $\begin{array}{l}\text { "A brief comparison of existing conditions to a 1983 } \\
\text { aerial photo indicates an erosion rate of 20 ft per } \\
\text { year" }\end{array}$ & $\begin{array}{c}\text { Legare, } \\
2000\end{array}$ & - & $\begin{array}{c}1983- \\
2000\end{array}$ & 6 \\
\hline $\begin{array}{l}\text { "Residents reported as much as 40 ft of beach was } \\
\text { eroded due to two coastal storms this fall" }\end{array}$ & $\begin{array}{c}\text { Legare, } \\
2000\end{array}$ & 12 & $\begin{array}{c}\text { Fall } \\
2000\end{array}$ & 12 \\
\hline $\begin{array}{l}\text { "Port Heiden reports losing over 100 ft of beach in } \\
\text { one section in the last 5 years" }\end{array}$ & $\begin{array}{c}\text { USACE, } \\
2007\end{array}$ & 30 & $\begin{array}{c}2002- \\
2007\end{array}$ & 6 \\
\hline $\begin{array}{l}\text { "The borough planner estimates that from the August } \\
\text { 2002 Port Heiden community profile map to the } \\
\text { present time there was about 200 ft of bank loss, } \\
\text { which is an average loss of 40 ft per year" }\end{array}$ & $\begin{array}{c}\text { USACE, } \\
2007\end{array}$ & 61 & $\begin{array}{c}2002- \\
2007\end{array}$ & 12 \\
\hline $\begin{array}{l}\text { "In one and one-half months [sic] time, the shoreline } \\
\text { embankment had eroded back from 10 to 40 ft." }\end{array}$ & NOAA,2007 & $3-12$ & 2007 & $3-12$ \\
\hline $\begin{array}{l}\text { "Locals estimate the yearly rate of erosion for 2011 to } \\
\text { be 10 ft [at the tank farm]" }\end{array}$ & $\begin{array}{c}\text { Stergiou, } \\
2013\end{array}$ & 3 & 2011 & 3 \\
\hline $\begin{array}{l}\text { "15 to 20 ft of inland erosion has been estimated } \\
\text { each year." }\end{array}$ & $\begin{array}{c}\text { USACE, } \\
2007\end{array}$ & - & - & $5-6$ \\
\hline
\end{tabular}




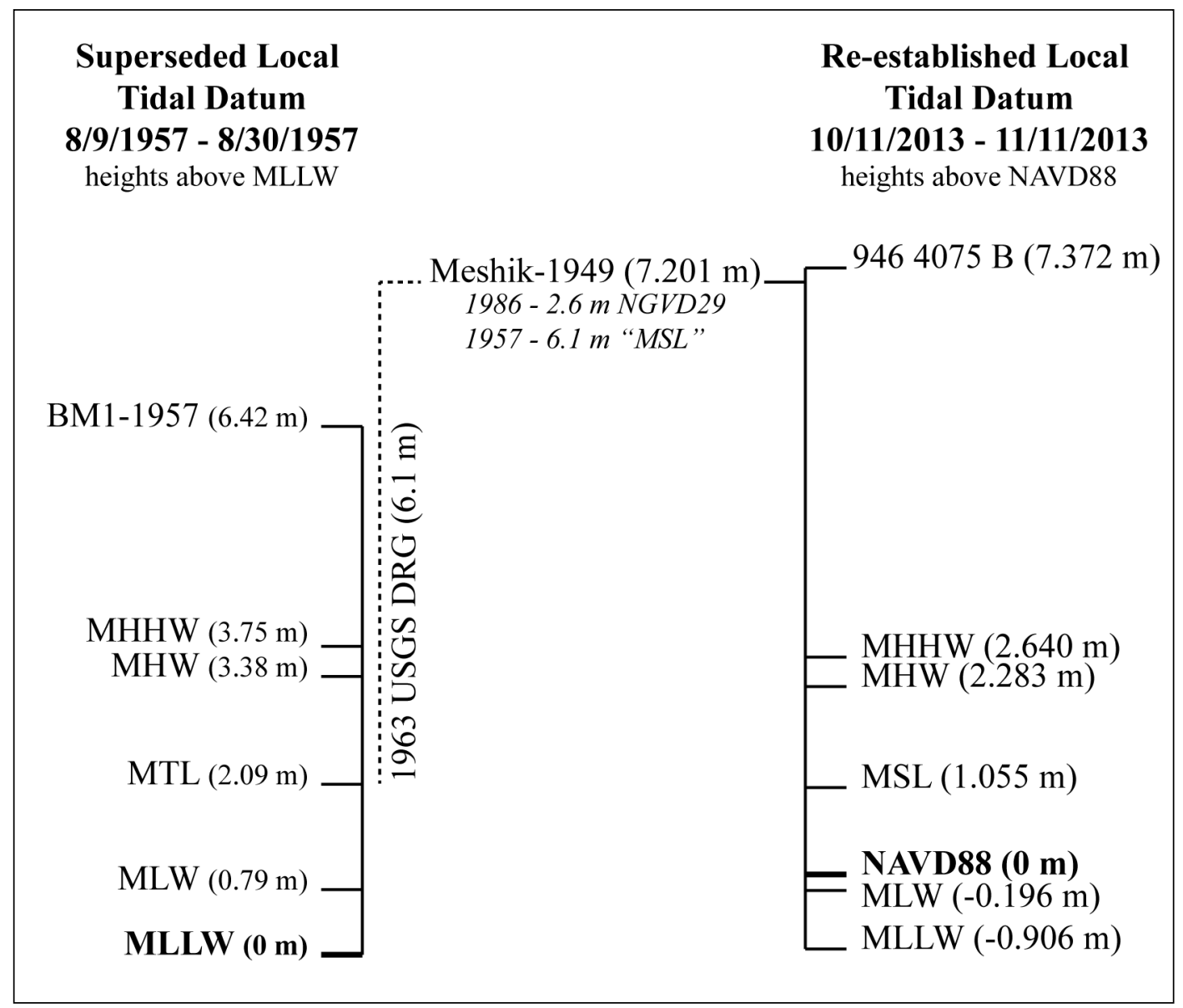

Figure 5. Comparison of the 1957 (NOAA, 2013) and 2013 tidal datums for Port Heiden, aligned through a common benchmark (Meshik-1949) of known elevation.

winter months. Hindcast offshore wave conditions near Port Heiden indicate a very dominant western swell and local wave climate (U.S. Army Corps of Engineers [USACE], 2012, Stn. 82260). One effect of these prevailing directions is a persistent wave setup condition that elevates water levels along the north side of the Alaska Peninsula and along the west-facing Meshik shoreline (Wise and others, 1987).

The majority of notable coastal storms in Port Heiden have been associated with severe northwest winds, often in excess of 31 knots (Kvasager, 1975; Wise and others, 1981). Low-pressure storm systems are most common in the late summer to early fall, although a short spring storm season is also not uncommon. Bristol Bay storm events are characterized by extreme winds and large waves that combine with significant swells up to $9 \mathrm{~m}$ that develop on the Aleutian Shelf due to the long fetch and extended storm durations. For any given system, severe weather can be sustained over Bristol Bay for extended periods of time as Pacific storm tracks stall against high pressure that prevails over mainland Alaska (Wise and others, 1987).

Although oceanographic and bathymetric conditions are favorable for the generation of extreme storm surges in Bristol Bay, there is no record of flooding in the developed parts of Port Heiden because the raised local topography protects these areas from coastal flooding (ACMP, 2007; Wise and others, 1981; USACE, 2013). The hazards that Port Heiden is most exposed to during severe storms are high winds and coastal erosion.

The presence of ice in the nearshore reduces wave energy associated with large storm events, and periods with limited to no shore ice protection correlate with some of the largest observations of bluff retreat at Meshik (fig. 6; Legare, 2000). Bristol Bay is at the southern limit of the seasonal sea ice extent for the Bering Sea; peak sea ice concentrations in this part of the Bay have historically ranged from open drift (30\% cover) to close pack ( $90 \%$ cover) from December to May, with maximum concentrations typically occurring in March. Since the 1950s, the record shows a gradual one-month delay in the initial arrival of pack ice to this portion of the coast. From 2000 through 2005, anomalous and extended open-water periods were present in mid to late winter (Historical Sea Ice Atlas [HSIA], 2014; ACMP, 2007). In Port Heiden, the alongshore ice concentrations and intermittent periods of land-fast ice are enhanced by localized freezing near the embayment mouth 


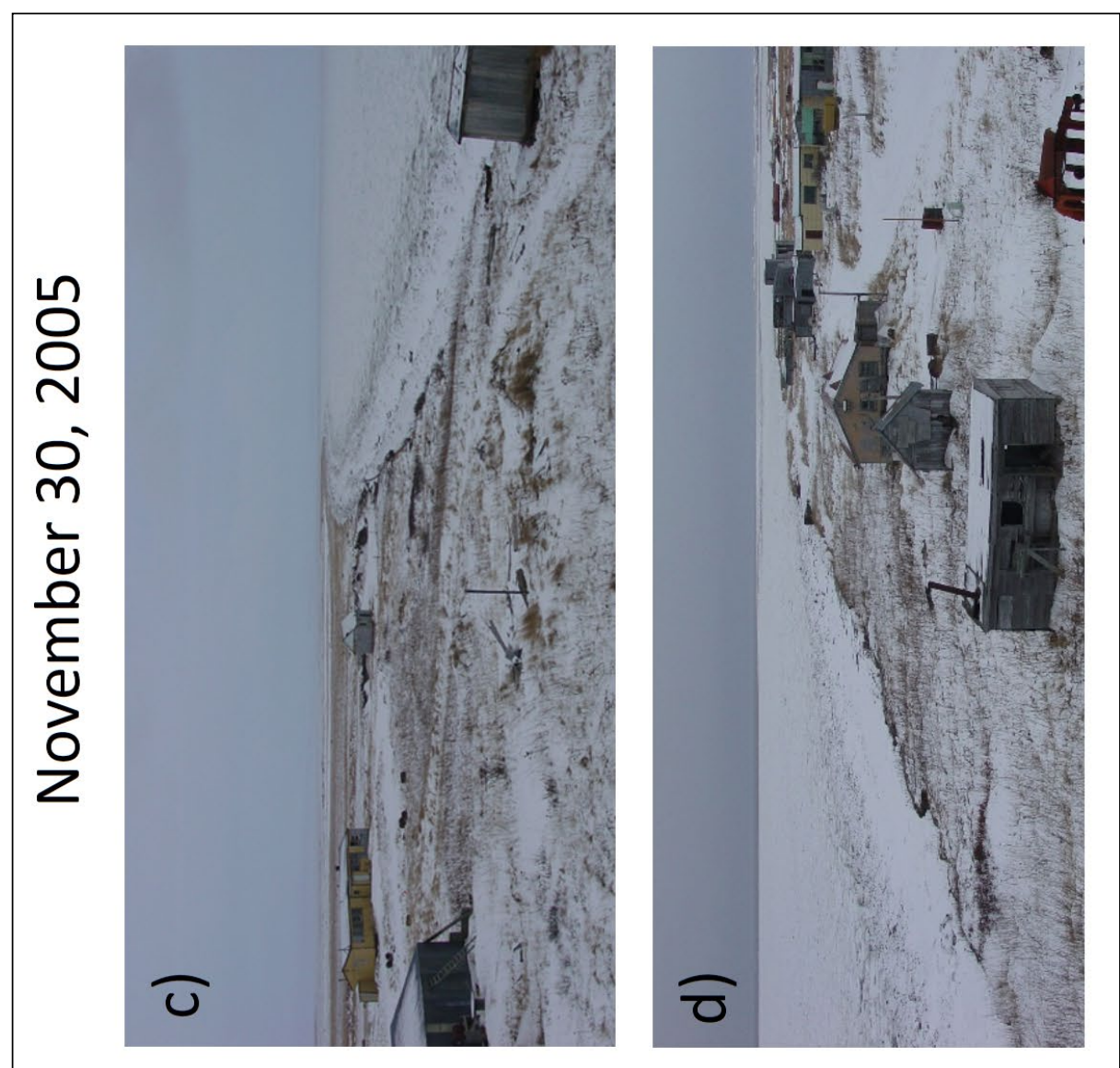

仓ํㅡㄹ

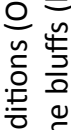

竞点

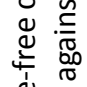

...

突

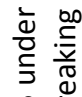

ํํㅇํํ

등

ह 3

동

in

高 $\overline{\overline{0}}$

ํํำ

与

$\stackrel{\varrho}{ \pm}$

त。

先

응

동

웜

ชิ

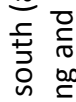

은 응

$\circ$

늠 वे

흔

党苍就

交市弯

을

ब

艺放合

․ㅡㅇ

这苍

$\leqq \frac{5}{n}$

는

过

需

๘

훙

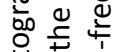

웡

듬 $\frac{.}{0}$

ט

产 
and sea ice accumulation during northerly wind events. If present, landfast ice near Meshik is often restricted to a narrow band along the coast due to strong longshore currents (Wise and others, 1987).

\section{REGIONAL GEOLOGY}

Surficial geologic mapping of the region was initially published in 1981 by Detterman and others based on surface observations in combination with interpretations from aerial photographs. The entire area has experienced net uplift due to glacial unloading and isostatic adjustment since the last glacial maximum. The Port Heiden landscape primarily comprises (1) glacial drift, (2) volcanic ash and pyroclastic flow and fall, (3) alluvium, (4) wetland, and (5) marine/beach deposits.

(1) The glacial drift deposits intersect with the shoreline approximately $5 \mathrm{~km}$ north of Meshik. These revegetated deposits consist of unsorted till and outwash of the Kvichak stade (approximately 25,000 yrs BP; Detterman and others, 1981) overlying undivided drift from older glacial advances in the area. Well-sorted and -stratified sediments form near-horizontal planes that are commonly cut by channels in the outwash deposits.

(2) Blanketing and abutting these glacial deposits are extensive pyroclastic flow (ignimbrite) and fall deposits, in irregular layers of varying thickness composed of unconsolidated and non-welded pumice and coarse ash. The most massive of these volcanic deposits are associated with the caldera-forming eruption of Aniakchak 3,595 $\pm 4 \mathrm{yrs}$ BP (Pearce and others, 2004). These bluffs at Meshik are composed of a highly erodible pumice-rich unit (fig. 7) capped by a thin organic layer.

(3) Alluvium is present south of Meshik and on the inland side of Port Heiden. These deposits contain moderately well sorted fine sand to gravel that is rich in volcanic materials and includes both active and inactive depositional environments.

(4) Fine-grained wetland deposits rich in organic material are present in the low-lying regions just north of the barge landing and on the southern and eastern sides of Goldfish Lake (Reger and others, 2003; Hogan, 1995; Detterman and others, 1981).

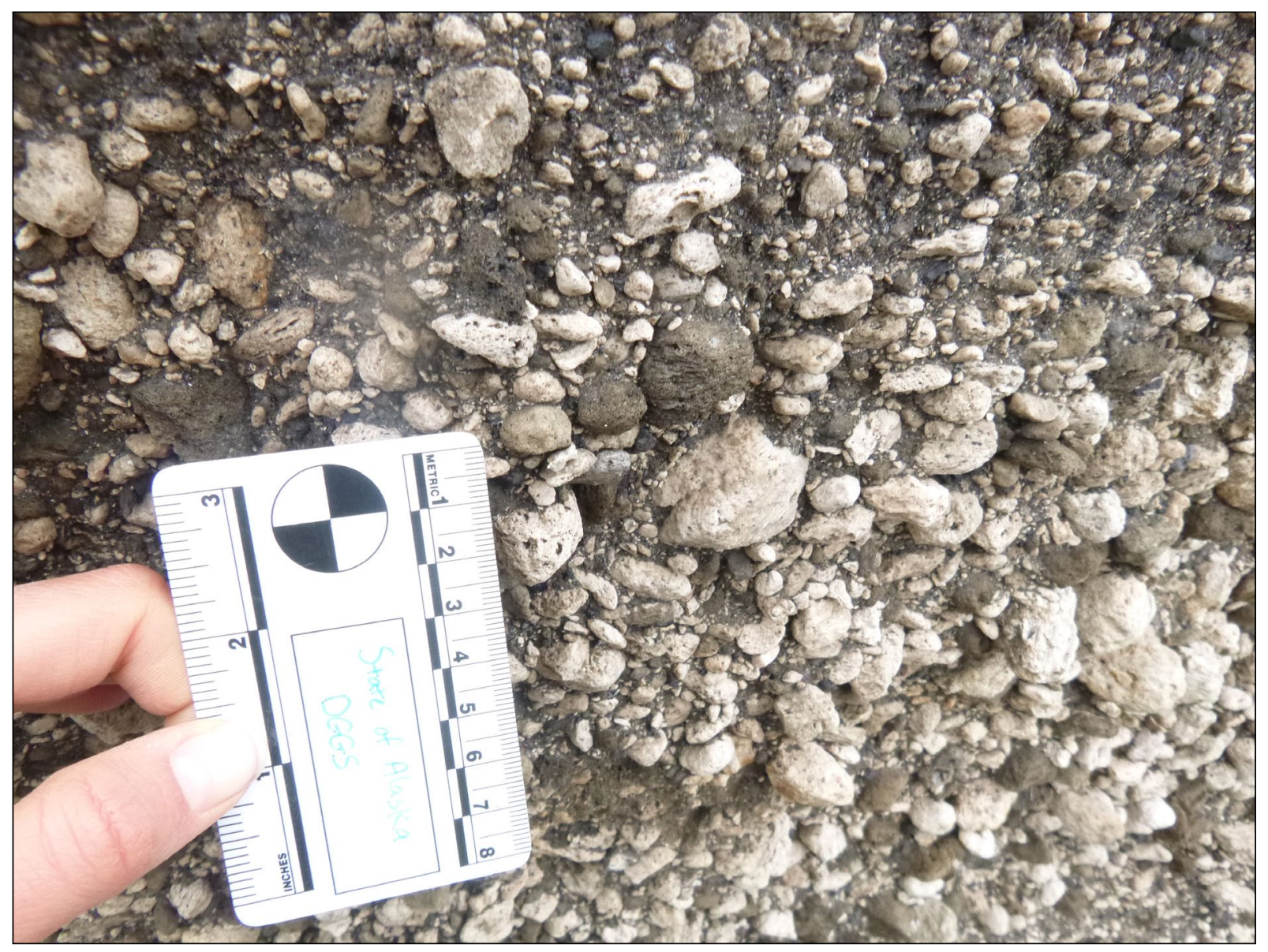

Figure 7. A close-up image of the pumice-rich bluff-forming unit. 
(5) Well-sorted and unconsolidated sand and gravels deposited within a coastal setting. See the Coastal Physiography section of this report for additional details on composition and characteristics.

Subsurface materials in both Port Heiden and the Meshik site are layers of sand to coarse, gravelly sand interbedded with thick layers of pumice deposits extending to at least $8 \mathrm{~m}$ below the surface and to depths of $60 \mathrm{~m}$ in some inland areas. Surface soils are generally poorly developed due to the frequent deposition of ash layers as recently as 1931. Permafrost in the area is discontinuous and no ice lenses were observed in any of the bluff faces (Iliaska Environmental, 2008; Hogan, 1995; Ferrians, 1965).

\section{COASTLINE PHYSIOGRAPHY}

The Bristol Bay coastline of the Alaska Peninsula is segmented by six large embayments that are protected from the open ocean by barrier islands and spits. The non-embayed beaches of this coast are typically backed by bluffs of varying height that are eroded into unconsolidated deposits, or by dunes. Port Heiden's position along this coastline is at approximately the point where the morphology switches from well-developed barrier island systems, typical of a wave-dominated coast, to barrier spits at embayment mouths, which are more typical of a tide-dominated coastline (fig. 4; Sallenger and Hunter, 1984). Water depths in the nearshore are shallow and emergent tidal deltas are not uncommon in the embayment mouths.

Meshik is located roughly $10 \mathrm{~km}$ from the downdrift boundary of the Port Heiden littoral cell that was first defined by Hunter and others (1979). Although net alongshore sediment transport in the Port Heiden littoral cell is toward the north, as indicated by spit orientation and river mouth offsets, Meshik is adjacent to a sediment-transport reversal that is localized to the mouth of the Port Heiden embayment. Littoral sediments on the beaches and spits are well sorted sands to gravel with abundant pumice float and glacially-derived cobbles visible at the surface. The average grain size, as determined from sieve analysis of 16 foreshore and backshore sediment samples, is classified as coarse sand $(0.5-1 \mathrm{~mm})$.

No littoral sediment budgets or net longshore sediment transport rates have been assembled for the Port Heiden littoral cell. Sieve analysis of a sediment sample from the pyroclastic layers that form many of the local bluffs revealed a high percentage ( $<40$ percent) composition of material sand-sized or greater. This suggests that erosion of these bluffs does not contribute a significant amount of material to the littoral budget. Examination of the shoreface composition indicated that the majority of the littoral sediments in the Meshik study area are sourced from local alluvial and glacial outwash deposits and from the remobilization of sediments in the offshore bars and barrier island system, including eroding portions of a recurved dune field to the north.

Coastal vegetation around Meshik is typical of tundra or sub-tundra coastlines, which include heaths, low alder, willow, and grasses with sphagnum and other water-tolerant plants in more poorly drained areas. Vegetation on the well-drained beach and dune deposits is principally ryegrass (Hogan, 1995).

\section{Contemporary shoreline evolution (1957-2013)}

Past documentation, estimates, or reports of shoreline retreat rates at Meshik have typically been associated with ongoing relocation or environmental remediation projects (summary in table 1). The U.S. Army Corps of Engineers identified Port Heiden as a Priority Action Community in the 2007 statewide Alaska Baseline Erosion Assessment; however, no detailed analysis was conducted, and the Port Heiden portion of this report only identifies an approximate linear extent of erosion based on community interviews. Estimated rates of erosion at Meshik ranged from 3 to $12 \mathrm{~m} / \mathrm{yr}$ and no rigorous shoreline change study had been previously completed for this area.

\section{Method for Calculating Shoreline Retreat Rates}

In this study, shoreline change was quantified by identifying the position of the shoreline in a series of eight vertical image sets spanning the period 1957-2013 (table 2). This assessment incorporates all publicly-available imagery that meets minimum resolution requirements. Alongshore rates of change were calculated using a linear regression technique in a Geographic Information System (GIS) environment with the Digital Shoreline Analysis System (DSAS v. 4.3; Thieler and others, 2009) tool developed by the U.S. Geological Survey. This tool constructs regularly-spaced virtual transects that intersect a set of temporal shoreline vectors. A $3.8 \mathrm{~km}$ segment of the coast from Abbott Creek to Barabara Creek was examined in this analysis of the Meshik study area, and rates were calculated at $50 \mathrm{~m}$ intervals (fig. 2).

Vertical images contain scalar errors, as well as radial and relief distortions that arise from variations in the sensor altitude and attitude relative to the surface, or from inherent optical lens properties. These distortions limit the usefulness of raw vertical images for shoreline change calculations because of positional uncertainties in the delineated shorelines, particularly in high-relief coastal environments such as those with bluff- or cliff-backed beaches (Moore, 2000). To mini- 
mize these uncertainties, all of the images used in this rate-of-change analysis were orthorectified using standard softcopy photogrammetry techniques (software used was BAE SocetGXP, AGIsoft Photoscan, or Exelis ENVI, as appropriate).

A series of eight temporal shoreline vectors were manually digitized from this compilation of orthorectified images. When available, the bluff top was chosen as a proxy indicator of the shoreline position because it is more consistent than the position of the bluff toe, is readily identified, is not dependent on tide-coordinated imagery for positional bias, and is process-linked to erosion mechanisms (Hapke and Reid, 2007; Crowell and others, 1991). When a bluff top was not present, the seaward limit of continuous vegetation (or vegetation line) was used as a secondary shoreline proxy. Types of vegetation lines in the area include stabilized dunes/berms and vegetated tundra surfaces truncated by erosion. The vegetation line was selected as a secondary proxy because it often coincides with the bluff top, is readily identifiable, and is typically reflective of the inland extent of littoral transport during extreme events on the decadal timescale (Ruggiero and others, 2013; del Río and Gracia, 2013; Boak and Turner, 2005).

Shoreline change rates are only as accurate as the underlying errors associated with each shoreline vector included in the analysis. The component uncertainties for the shorelines derived from vertical aerial photographs or satellite images (modified from Hapke and Reid, 2007) include:

$U_{p}$ Positional uncertainty associated with the ground control that was used to georeference the imagery. For most of the images used in this study, the photogrammetric control was from a differential GPS field survey $(<0.1 \mathrm{~m})$. For the 1963 imagery, control was from an independently orthorectified product $(=2.6 \mathrm{~m})$.

$U_{o}$ Uncertainty associated with distortion reduction and positioning in the orthorectification process. This is the horizontal RMS error associated with the sensor model and block alignment, as calculated in the photogrammetry software (see table 2 for values).

$U_{i} \quad$ Uncertainty due to the identification and delineation of the shoreline indicator. This is dependent on the image pixel scale, which ranged from 1:650 (1963) to 1:9,500 (2011) and was assumed to be $0.5 \mathrm{~mm}$ at the image scale (see table 2 for values; after Crowell and others, 1991; Moore, 2000).

$U_{d}$ Digitizer/operator uncertainty due to interpretation of the shoreline proxy position in the manual digitizing process. To quantify this error, a representative shoreline vector was independently digitized by each of the authors. This is the RMS error of the differences between these shoreline vectors at all of the virtual transects included in this study $(=1.4 \mathrm{~m})$.

The total shoreline positional uncertainty ( in table 2) at each transect location is the square root of the sum of the squares of these component uncertainties, assuming that each term is independent:

$$
U_{t}=\sqrt{U_{p}^{2}+U_{o}^{2}+U_{i}^{2}+U_{d}^{2}}
$$

The shoreline change assessment was enhanced with site visits to the Port Heiden area in August and October 2013. These visits included the collection of coastal elevation profiles using a survey-grade GPS system consisting of two dual-frequency Topcon HiPer II GNSS receivers and an FC-250 field controller running TopSURV software. With post processing, this configuration typically yields total vertical uncertainty of $<5 \mathrm{~cm}$ (Kinsman and DeRaps, 2012). Repeat elevation profiles were collected at four transects in the study area in October 2013. Plots of these revisited coastal profiles are presented in figures 8 and 9. Transect-specific erosion rate estimates were enhanced by reports from local observers, including city officials, Local Environmental Observers (LEO), and student and faculty pilot members of Alaska Corps of Coastal Observers (AkCCO) at the Meshik School.

Table 2. List of the eight temporal shoreline vectors, the image sources and dates, and the combined horizontal uncertainty associated with each proxy shoreline position (U_t).

\begin{tabular}{|l|l|c|c|c|}
\hline \multirow{2}{*}{ Shoreline } & \multicolumn{1}{|c|}{ Type } & \multicolumn{2}{c|}{ Variable component errors } & \multirow{2}{*}{$\boldsymbol{U}_{\boldsymbol{t}}(\mathbf{m})$} \\
\cline { 3 - 4 } & & $\boldsymbol{U}_{\boldsymbol{o}} \mathbf{( m )}$ & $\boldsymbol{U}_{\boldsymbol{i}}(\mathbf{m})$ & \\
\hline $1957-$ June/July & Aerial & 2.87 & 2.30 & 3.95 \\
\hline $1963-$ August 20 & Aerial & 3.17 & 0.32 & 4.38 \\
\hline $1973-$ June 22 & Aerial & 1.63 & 2.88 & 3.61 \\
\hline $1983-$ August 26 & Aerial & 2.12 & 3.15 & 4.07 \\
\hline $2002-$ June 17 & Aerial & 2.10 & 0.58 & 2.61 \\
\hline $2009-$ June 26 & Satellite GeoEye-1 & 2.64 & 0.98 & 3.16 \\
\hline $2011-$ May 1 & Satellite SPOT-5 & 6.46 & 4.72 & 8.13 \\
\hline $2013-$ June 17 & Satellite Worldview-2 & 1.04 & 0.94 & 2.01 \\
\hline
\end{tabular}




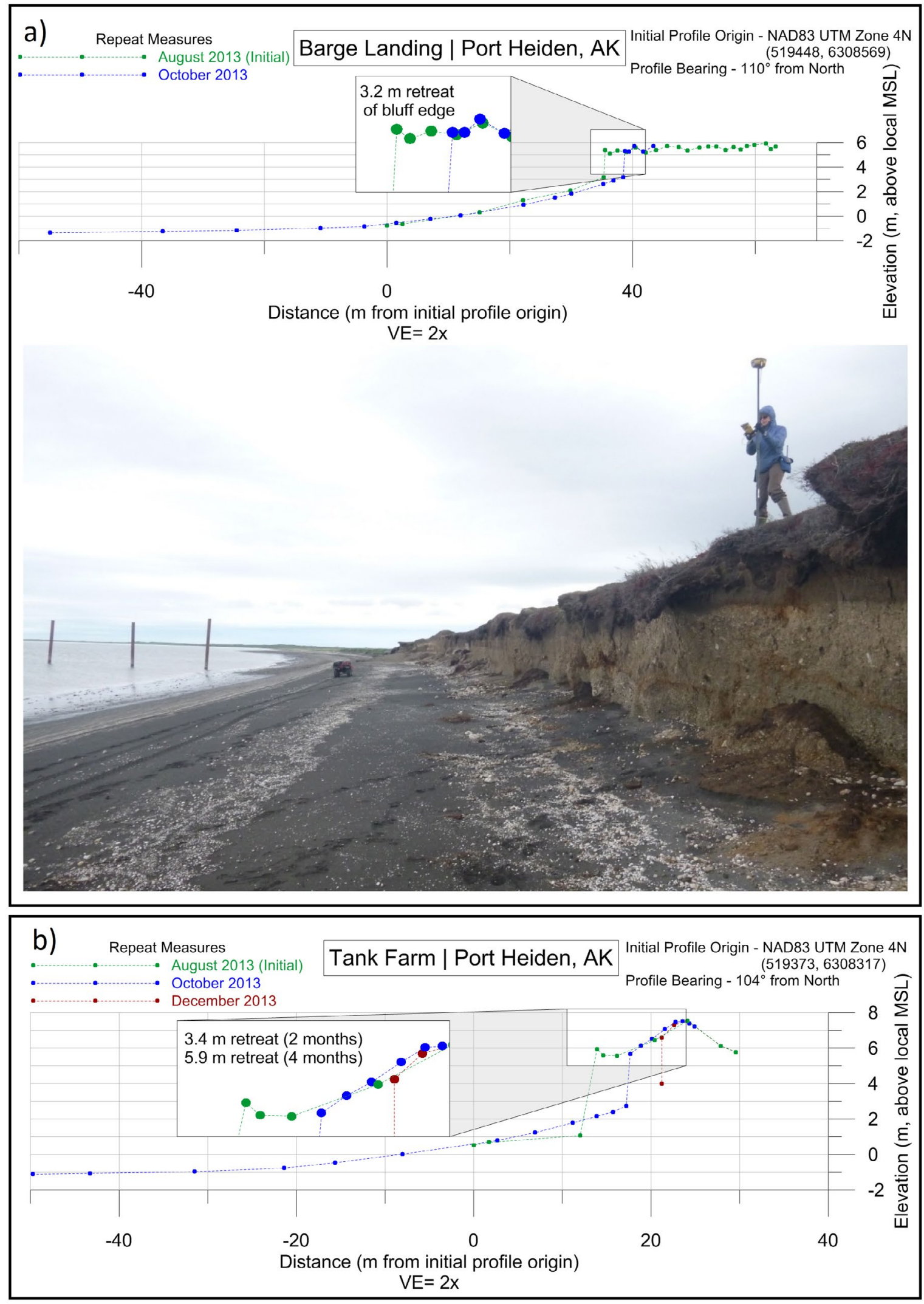

Figure 8. Plots of repeat coastal elevation profiles at the (a) Barge Landing and (b) Tank Farm transects (see fig. 2 for locations). The plot of the Barge Landing transect is accompanied by a photograph taken during the August survey. 

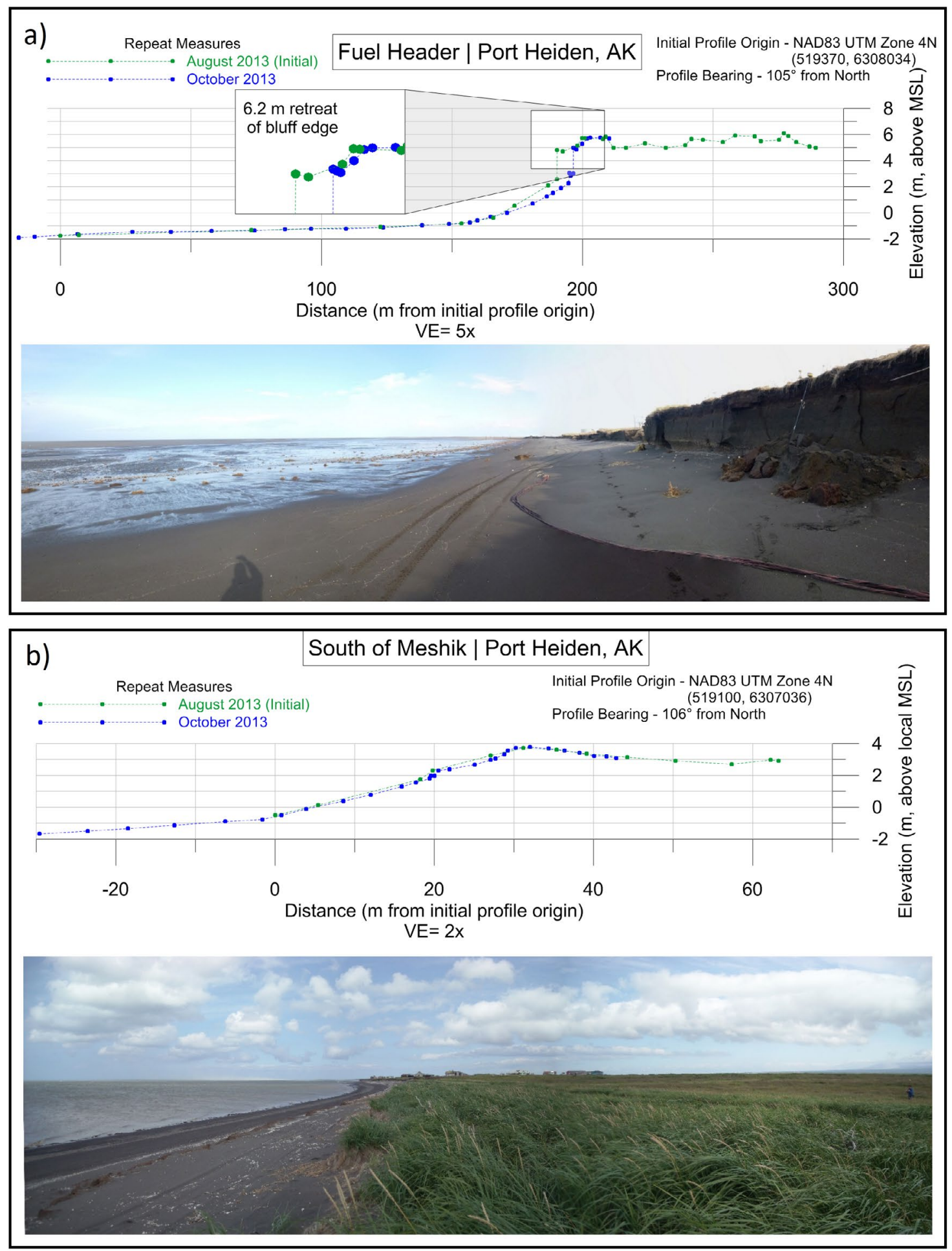

Figure 9. Plots of repeat coastal elevation profiles at the (a) Fuel Header and (b) 'South of Meshik' transects (see fig. 2 for locations). The plot of the Fuel Header transect is accompanied by a photograph taken during the October survey; recent block failures are visible at the toe of the bluff. The plot of the 'South of Meshik' transect is accompanied by a photograph taken during the August survey; this transect is south of the bluffs in a low, dune-backed environment on the southern spit. 


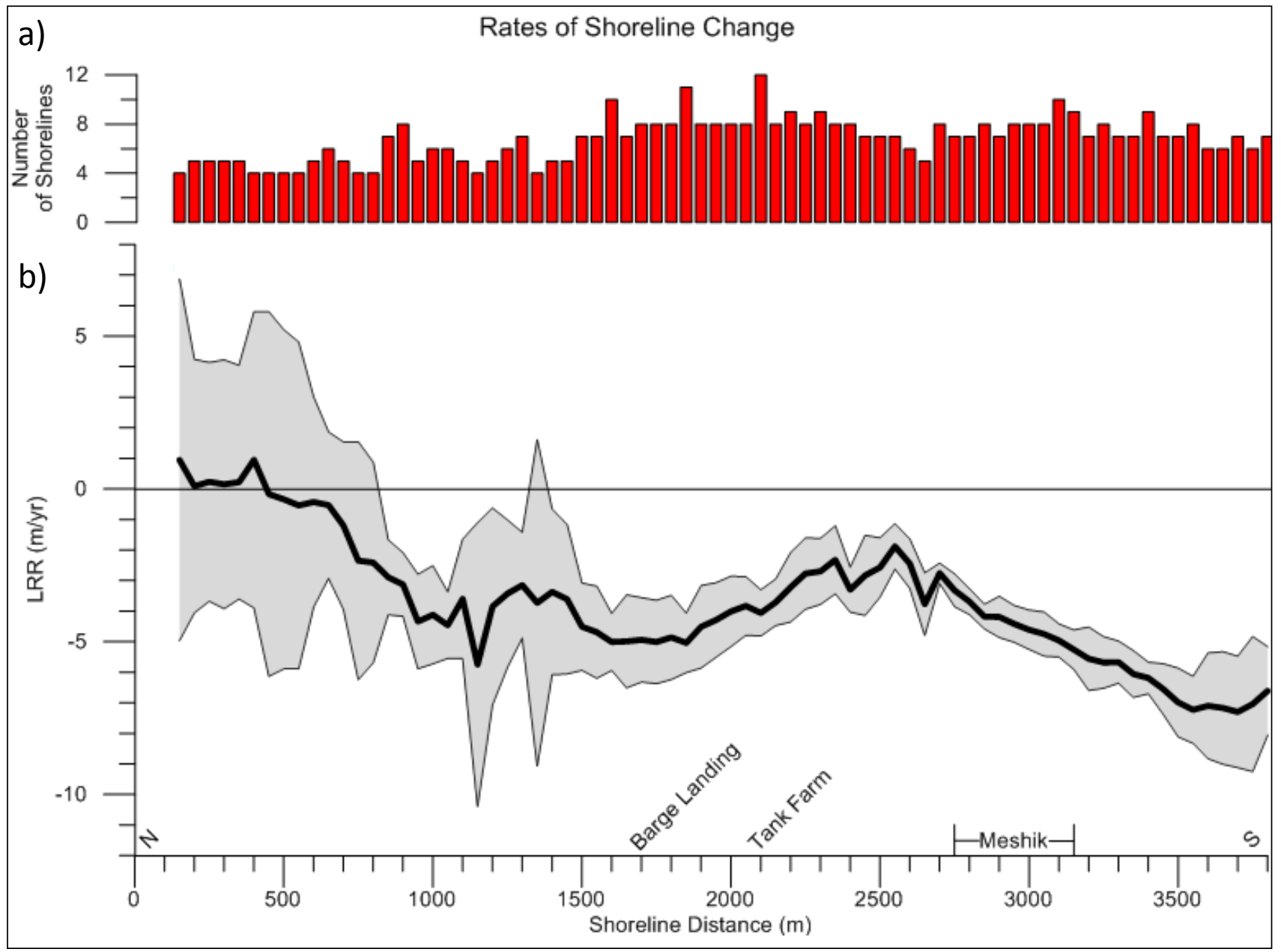

Figure 10. (a) Number of viable shoreline proxy positions at each virtual transect position from north $(\mathrm{N})$ to south $(\mathrm{S})$ in the study area. (b) Alongshore linear regression rates (LRR) of long-term shoreline change with associated uncertainty shown in gray. Uncertainty is higher in non-bluff areas where the vegetation line is both more variable and more difficult to identify, as well as in areas with fewer valid shoreline vectors. Positive linear regression values represent progradation and negative values correspond to erosion.

The long-term (56-year) shoreline change rate at each transect is the slope of the calculated linear regression through all viable shoreline positions (fig. 10). This rate-of-change calculation is widely employed in shoreline change studies, and linear regression performs well in environments where unidirectional shoreline change prevails and the positional uncertainties are similar across the fulltime series (Dolan and others, 1991; Himmelstoss, 2009). A drawback to the use of linear regression rates is that a constant rate of change is assumed across the entire time series. To assess possible acceleration or deceleration of erosion rates through time, a simple annualized end-point rate was calculated across each time step in the dataset at three representative transects in the study area (fig. 11).

The erosion rates presented in this report are affected by the seasonal and episodic variability that characterizes all active coastal environments. While the shoreline change rates have been presented in units of meters per year, it is important to note that these annualized averages are far lower than typical rates for a specific high-energy erosional event such as a fall storm. At any virtual transect location where a retreat rate has been calculated, the majority of the net annual retreat represented by this rate is likely associated with just a few severe storms confined to several days. To reduce the effect of this seasonality, all aerial or satellite images that were incorporated into this analysis are from more stable summer months, between May and August.

\section{Results}

For ease of interpretation, all of the calculated long-term shoreline change rates are presented in map view as a graphical band along the coast (fig. 12). At most of the virtual transect locations the change in the position of the shoreline proxy 


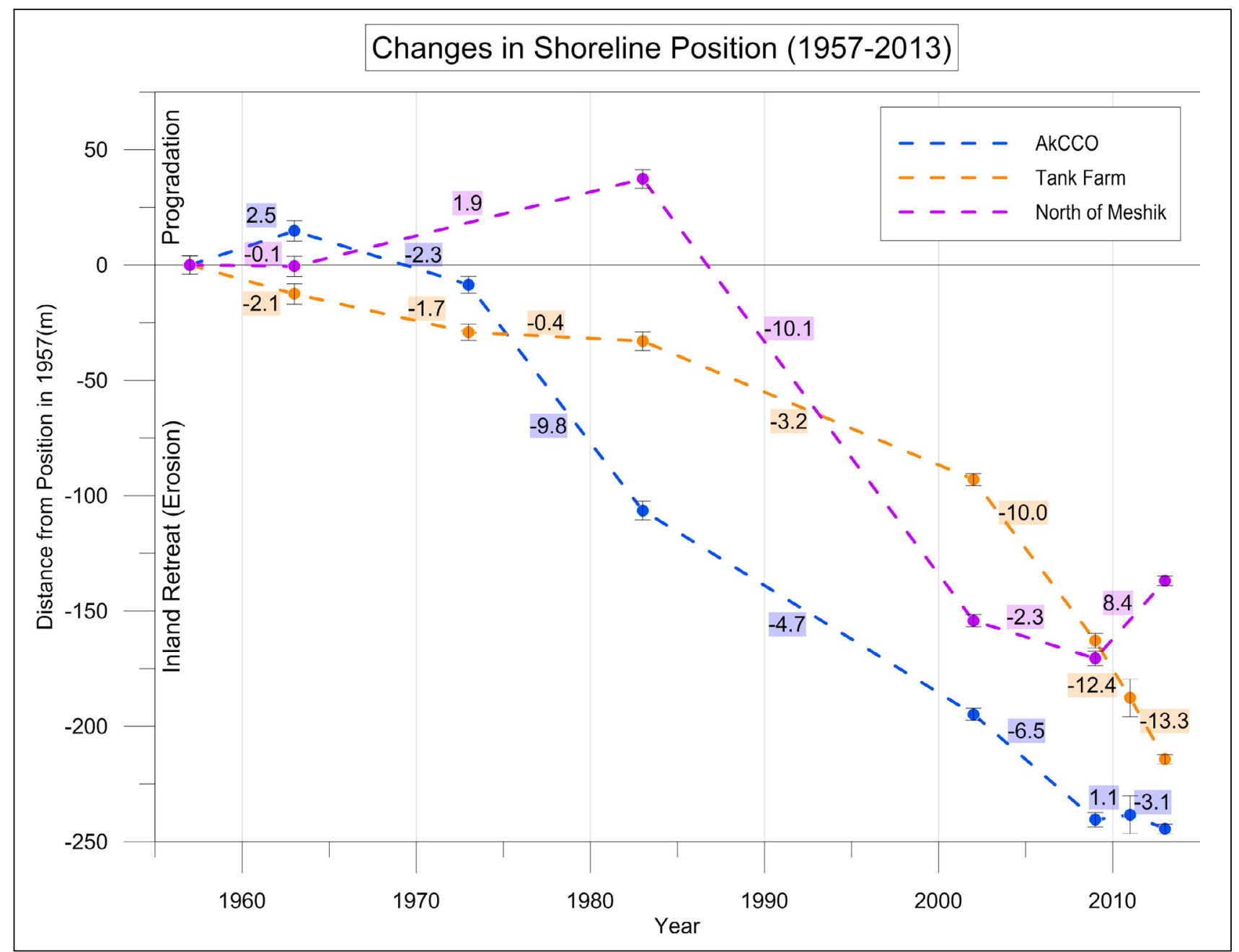

Figure 11. Position of the shoreline through the entire time series relative to the position in 1957 at three representative transects (see fig. 2). The slope of each line segment is the short-term or annualized endpoint rate for each time step, shown as $\mathrm{m} / \mathrm{y}$ in the adjacent colored boxes.

was unidirectional throughout the entire time series. Peak long-term rates of shoreline change in this study area (retreating $7.3 \pm 1.8 \mathrm{~m} / \mathrm{yr}$ ) are found south of Meshik, near Barabara Creek at the proximal end of the southern barrier spit. Negligible rates of long-term change are present in the lee of the northern barrier spit, near Abbott Creek.

High long-term shoreline retreat rates are present in the vicinity of the barge landing site $(4.9 \pm 1.4 \mathrm{~m} / \mathrm{yr})$ and at the tank farm $(4.1 \pm 0.8 \mathrm{~m} / \mathrm{yr})$. Recent seasonal retreat rates at these locations are much higher, as illustrated in figures 8 and 11 , where $>3 \mathrm{~m}$ of erosion occurred only partway through the 2013 storm season. At the Fuel Header transect, the bluff edge retreated inland $>6 \mathrm{~m}$ between August and October 2013 (fig. 9) and by November, the fuel header pipes had been fully undercut (fig. 13; Alaska Native Tribal Health Consortium [ANTHC], 2014). At the Meshik village site itself, longterm rates of shoreline retreat vary from 3.3 to $5.3 \pm 0.5 \mathrm{~m} / \mathrm{yr}$, with increasing retreat rates from north to south. Some of the lowest rates of shoreline retreat in the study area $(1.9 \pm 0.7 \mathrm{~m} / \mathrm{yr})$ are present at the convexity in the coastline that is between the tank farm and Meshik.

\section{DISCUSSION}

\section{Mechanisms and Patterns of Erosion}

The poorly-welded volcanic-rich tuff deposits that comprise the majority of the bluffs in the study area are highly erodible. Based on the measured profiles in the study area, the approximate elevation at the toe of these bluffs is only $1-2 \mathrm{~m}$ above the local MHHW level. Even during moderate storm surges, the total water surface will frequently exceed the elevation at the toe of these bluffs, which allows marine energy to translate across the narrow beach and results in extended periods of 


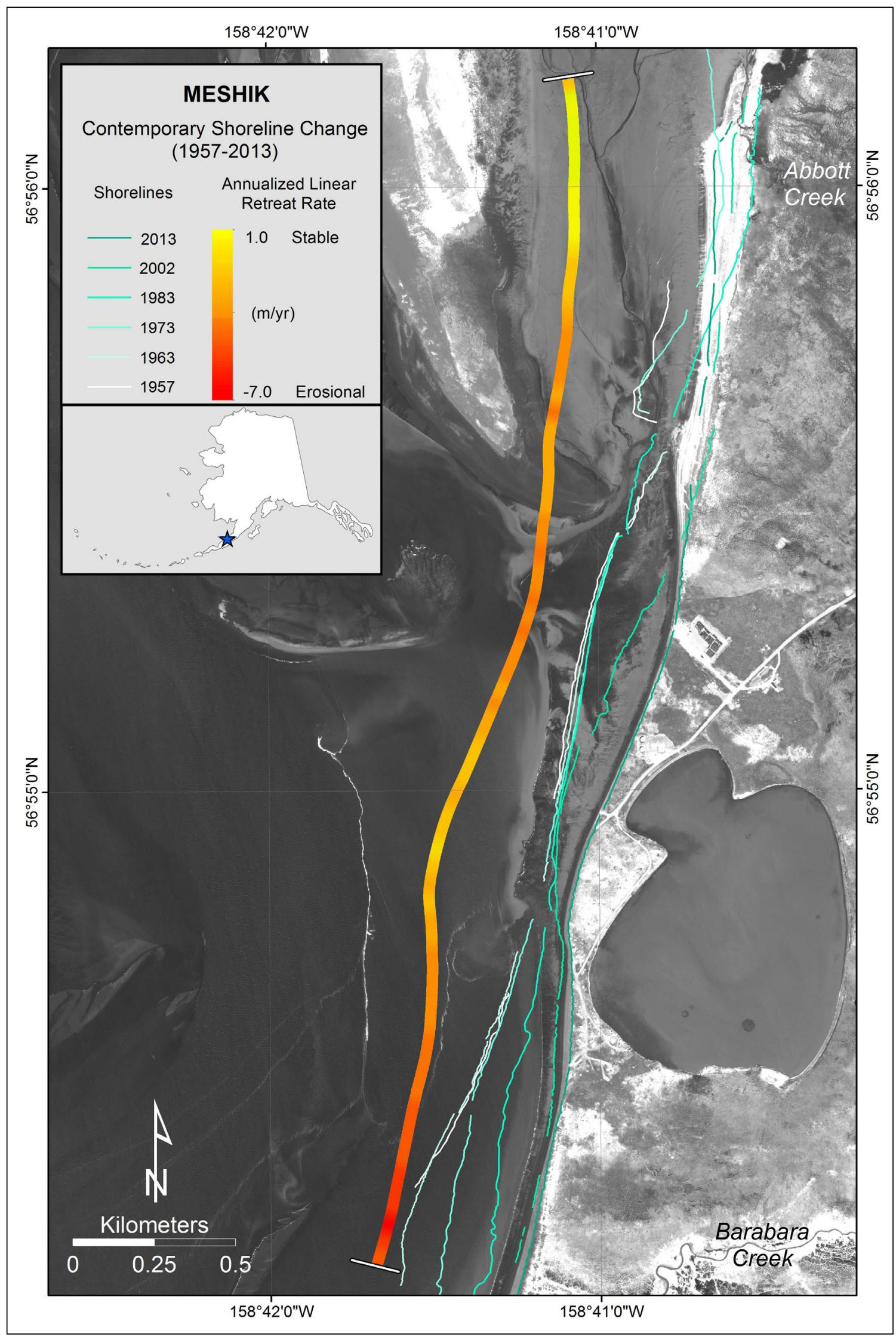

Figure 12. Long-term shoreline change rates for the entire study area, presented as a graphical band along the coast. A subset of the shoreline vectors used in the underlying analysis are plotted in shades of green. 


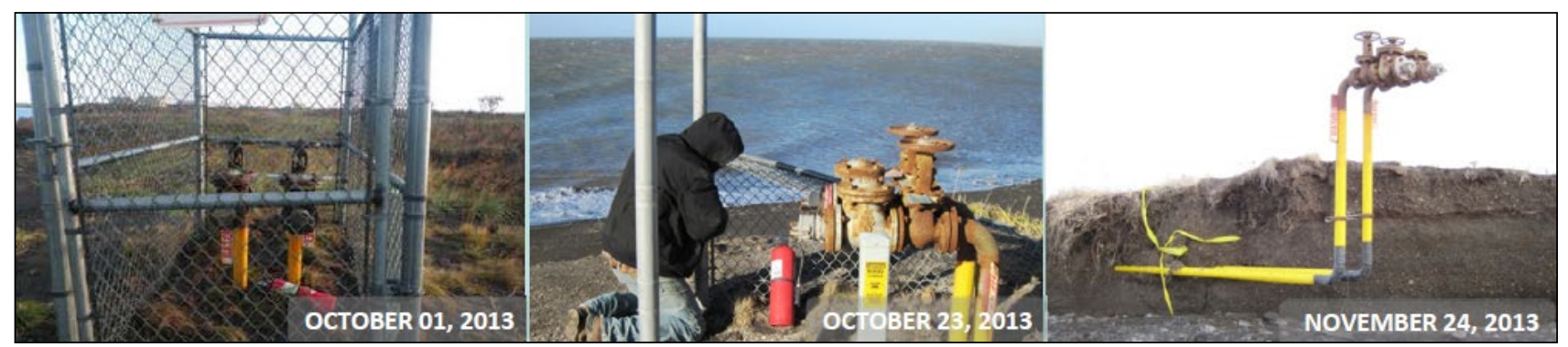

Figure 13. Fuel header pipes for Port Heiden's bulk fuel farm undercut by the eroding bluff during the 2013 storm season (photos by Linda Anderson, LEO).

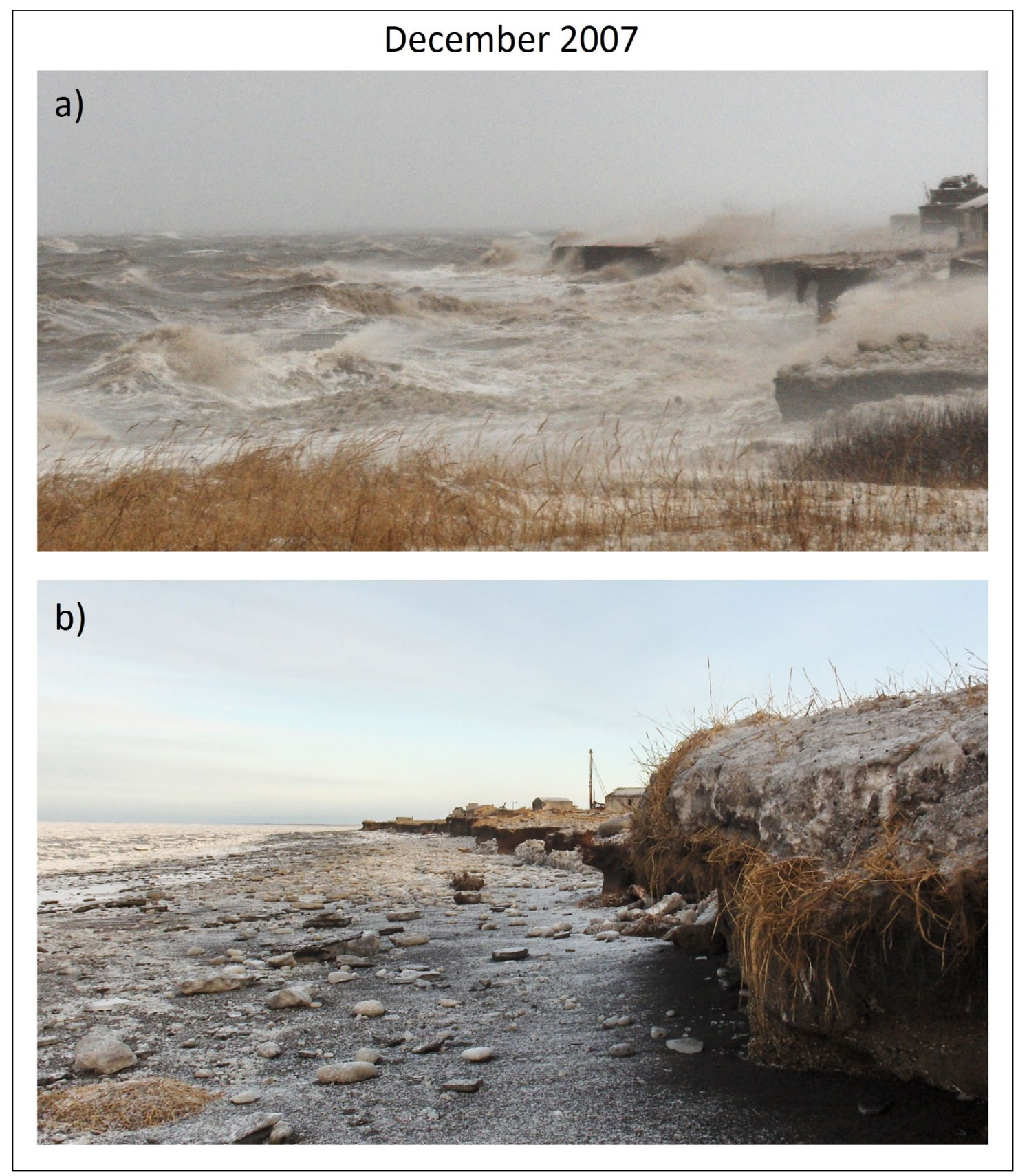

Figure 14. Photographs of the Meshik bluffs both (a) during and (b) immediately after a December 2007 storm. Note the undercutting at the base of the bluff from direct wave impact (photos by Scott Anderson). 
direct and sustained wave impact to the face of the bluff (fig. 14). During these storms, the pumice-rich bluffs are readily steepened and undercut by the hydraulic wave action and abrasion, and a single location may experience more than one slip or block failure in the same storm event.

Notably, the bluff-forming volcanic unit is so easily transported that talus deposits at the base of the bluffs only persist post storm when the failure occurs after storm water levels have receded. Unlike many coastal talus deposits, which temporarily serve as a protective buffer from additional marine erosion (Sunamura, 1992), these deposits are swiftly removed in subsequent storm events. Since most of the shoreline retreat in the Meshik study area is directly caused by marine energy, storm surge heights and wave impact hours are a primary control on the net amount of shoreline retreat that will occur over the duration of an individual event. Therefore, the timing of a surge event in the tidal cycle and other factors that contribute to the total water level, such as wind-driven setup, are extremely important drivers of erosion at Meshik.

The high erodibility of these bluffs is one of the cited factors for why relocation strategies have been favored over mitigation approaches, such as armoring, at the Meshik site. For example, in 1975, an 'embankment structure' project that utilized sediment-filled fuel drums from the dump site was briefly proposed; this project was never pursued because any type of hardened coastal engineering approach will be easily outflanked by the rapid retreat rate in adjacent, unarmored areas (Kvasager, 1975).

Much of the alongshore variation seen in the rates of shoreline change in this study area can be attributed to wave transformation in the nearshore. As waves approach the shallow depths along the coast, they will shoal and refract (or bend) in response to the underlying water depths; the result of this is a focusing of wave energy in deeper areas, such as at the channel near the barge landing, or in the southern part of the study area where the tidal flat is much narrower. The barge landing site is also subject to waves that diffract around the tip of the barrier spit directly offshore.

\section{Coastline and Landform Modification}

On the basis of the measured long-term rates of erosion, we can make some basic predictions about the future of the Meshik village site. For example, we can estimate the number of years before Goldfish Lake will be drained by a breach on the ocean side. Based on the shoreline change analysis, the breach is most likely to occur where the lake cuts close to the coast on its southern edge. Long-term rates of erosion at this location are $3.7 \pm 0.4 \mathrm{~m} / \mathrm{yr}$ and there are only about $54 \mathrm{~m}$

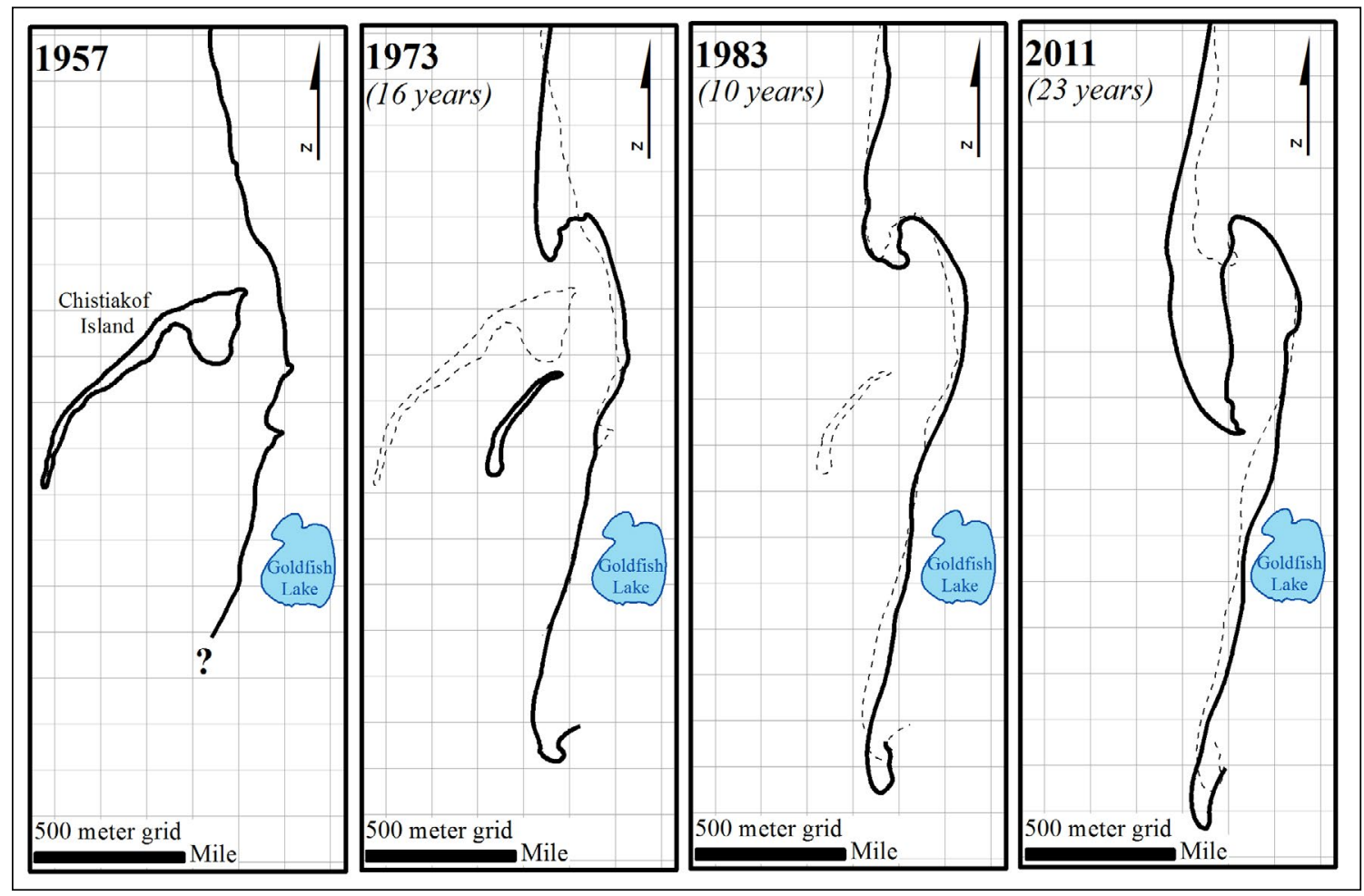

Figure 15. Diagrammatic series of shorelines (digitized from the instantaneous water line) in and around the Meshik study area from 1957, 1973, 1983, and 2011 that illustrate the reworking of the barrier system. Each time step after 1957 depicts the previous shoreline position as a dashed line. Goldfish Lake is shown to orient the reader to Meshik. 
between the bluff edge and the lake. These rates suggest that a breach could occur in approximately $15 \pm 6 \mathrm{yr}$ if the observed rates of retreat are maintained at their current level.

Sometime between 1973 and 1983, the sediments that composed Chistiakof Island were reworked and the barrier island welded onto the mainland, forming a spit that departs from the shoreline north of Goldfish Lake (fig. 15). Recurve dunes at the distal end of the incipient spit, visible in the 1973 imagery, began to form before the island totally disappeared. The spit south of Goldfish Lake has also been lengthening since the removal of the barrier island.

The natural reconfiguration of the barrier spit has had several significant impacts on the dominant alongshore processes that are shaping this coast. First, Chistiakof Island functioned as a dissipative barrier that blocked direct wave attack to the erodible bluffs at Meshik. When this barrier migrated, it exposed the townsite and created a low-energy wave environment in the lee of the newly formed spit. Second, the attached spit is a barrier to longshore sediment transport that previously occurred from north to south at the mouth of Port Heiden embayment. Sediments that were once transported southward and deposited at the toe of the Meshik bluffs are now deposited on the spit itself, or in the low-energy environment that is infilling the lee of the spit. Last, the spit is gradually accreting southward at a rate of approximately $1 \mathrm{~km}$ per decade. As it extends, the waves that diffract around the tip of the spit are focused progressively southward, resulting in a hot spot of erosion that is migrating southward as well.

This migrating pattern of accelerated erosion is most apparent in the time series of annualized erosion rates at the three representative transects shown in figure 11. All three of these transects exhibited stable accretion or net retreat of $<2.3 \mathrm{~m} /$ yr prior to the 1970s. Sometime after 1974, erosion at the AkCCO site increased to an annualized rate of $>4.7 \mathrm{~m} / \mathrm{yr}$, until very recently. This rapid retreat is most likely the result of re-equilibration of the coastline following the decrease in the sediment supply from the north and the increase in direct wave energy from the disappearance of Chistiakof Island. Shoreline retreat at the representative transect 'North of Meshik' also exhibits a rapid acceleration in the rate of retreat in the $1980 \mathrm{~s}$ and ' $90 \mathrm{~s}$, around the time this portion of the coast would have been newly exposed to direct wave attack. A marked deceleration and recent reversal in the shoreline change rate occurred around 2000, when the northern spit had accreted enough material to protect this section of the coastline. The site of the fuel tank farm is currently experiencing some of the most rapid annualized erosion rates observed across the entire time series $(13.3 \mathrm{~m} / \mathrm{yr})$. The rates of retreat at this location have been accelerating since the 1980s.

An outstanding question in the contemporary evolution of this shoreline is what triggered the migration and eventual mainland-welding of Chistiakof Island in the 1980s. There is some evidence that the island was lost in a single catastrophic storm (ACMP, 2007), however, the aerial image series suggests that the total area of the island had been incrementally decreasing for at least a decade before it disappeared totally. Appreciable changes in coastal systems are typically correlated to threshold shifts or events that redefine the equilibrium conditions. It is possible that a single large storm was the final factor in the reconfiguration of the barrier sediments near Meshik, but this storm most likely manifested a change representative of a broader shift in the conditions at this coast. The reanalysis of the local tidal datums provided in this study reveal a stable relative sea level over the period of observed change, allowing us to rule out reconfiguration of the barrier system due to a rising sea level.

Oceanographic measurements and models have identified an increase in storminess from the North Pacific to the Arctic since the 1950s (for example, Francis and others, 2011; Karl and others, 2009). This trend can be attributed to both an increase in the frequency and intensity of Northern Pacific storm tracks (Bromirski and others, 2013) and a poleward shift in the directional track of the storm systems (Chu and others, 2013; Mesquita and others, 2010). These trends are compounded by a shift in the Pacific Decadal Oscillation (PDO) that has been associated with wind anomalies in the vicinity of the Aleutian low (Hartmann and Wendler, 2005). This shift occurred in 1976, around the same time that the barrier island was completely removed.

Beaches can be classified by dominant marine energy regimes (wave, tide, or mixed) based on representative morphologies. In 1984, Sallenger and Hunter classified Port Heiden as a mixed-energy coastline and noted that this part of Bristol Bay marks the northward limit of extensive barrier islands and a transition into embayments enclosed by barrier spits. Given Port Heiden's position at the transitional point in Bristol Bay, we might expect that this portion of the coast would be particularly vulnerable to shifts in the relative influence of tide energy versus wave energy. Reconfiguration of barrier systems from drumstick islands to spits with dune complexes has been associated previously with shifts from mixed to wave-dominated energy regimes (Davis and Hayes, 1984) or by long-term changes in the directional wave climate (Horikawa, 1988). In the context of a trend toward increased storminess, the decadal shift in the PDO pattern and the approximate 1-month delay in the annual arrival of sea ice, it is likely that an increase in the relative amount of wave energy to tide energy at the coast has resulted in a shift to the wave-dominant energy regime at the Meshik study area.

\section{Future Work}

Ongoing work by DGGS staff will be extending the investigation of shoreline change in Port Heiden to $70 \mathrm{~km}$ of coastline encompassing the Meshik site. We will also be working with NOAA and other partners to hindcast storm-surge 
elevations, which will allow us to correlate wave impact hours at the bluff toe with the rates of retreat and to determine if the magnitude, duration, and frequency of storms have exhibited a net increase in recent decades. This work will also aid in the development of storm-surge recurrence intervals for this segment of the Alaska coastline.

Additional field data, including grain sizes, elevation profiles, and geomorphic classification will be processed for publication. Full maps of alongshore change rates and detailed elevation profiles from $70 \mathrm{~km}$ of the Port Heiden coast will be released in an online interactive format with an accompanying DGGS report.

\section{ACKNOWLEDGMENTS}

This preliminary interpretive report was funded with qualified outer continental shelf oil and gas revenues by the Coastal Impact Assistance Program, U.S. Fish \& Wildlife Service, U.S. Department of the Interior. The views and conclusions contained in this document are those of the authors and should not be interpreted as representing the opinions or policies of the U.S. Government. Mention of trade names or commercial products does not constitute their endorsement by the U.S. Government. Establishment of a new tidal datum for Port Heiden was funded in part by a 2013 grant through the Alaska Ocean Observing System. Reoccupation of geodetic benchmarks and the vertical velocity calculation for the area were conducted by Kimberly Tweet with funding provided by the Western Alaska Landscape Conservation Cooperative.

Special thanks to Scott Anderson (City of Port Heiden), Linda Anderson (Local Environmental Observer), Derek Luke (Lake and Peninsula School District) and the Alaska Corps of Coastal Observers (AkCCO) students at Meshik School for their photographs, keen observations, and ever-reliable field measurements. Additional thanks are extended to Meagan DeRaps, Kimberly Tweet, and Lauren Southerland (DGGS) who contributed to the collection of the data necessary to complete this report. Richard Koehler (DGGS), Scott Anderson, and Tatton L. Suter (USACE) provided insightful reviews that improved the final manuscript.

\section{REFERENCES}

Alaska Coastal Management Program (ACMP), 2007, Lake and Peninsula Borough Coastal Management Program, Final Plan Amendment, $254 \mathrm{p}$.

Alaska Native Tribal Health Consortium (ANTHC), 2014, Coastal erosion disrupts bulk fuel farm: January 7, 2014, Local Environmental Observer (LEO) Network, available online, http://www.anthc.org/chs/ces/climate/leo/.

Boak, E.H., and Turner, I.L., 2005, Shoreline definition and detection-A review: Journal of Coastal Research, v. 21, no. 4, p. 688-703.

Bromirski, P.D., Cayan, D.R., Helly, John, and Wittmann, Paul, 2013, Wave power variability and trends across the North Pacific: Journal of Geophysical Research, Oceans, v. 118, no. 12, p. 6,329-6,348, doi:10.1002/2013JC009189.

Chu, Cuijiao, Yang, Xiu-Qun, Ren, Xuejuan, and Zhou, Tianjun, 2013, Response of northern hemisphere storm tracks to Indian-western Pacific Ocean warming in atmospheric general circulation models: Climate Dynamics, v. 40, no. 5-6, p. 1,057-1,070, doi:10.1007/s00382-013-1687-y.

Crowell, Mark, Leatherman, S.P., and Buckley, M.K., 1991, Historical shoreline change—Error analysis and mapping accuracy: Journal of Coastal Research, v. 7, no. 3, p. 839-852.

Davis, Richard A., Jr., and Hayes, Miles O., 1984, What is a wave-dominated coast?: Marine Geology, v. 60, no. 1-4, p. 313-329, ISSN 0025-3227, doi:10.1016/0025-3227(84)90155-5.

Del Río, Laura, and Gracia, F.J., 2013, Error determination in the photogrammetric assessment of shoreline changes: Natural Hazards, v. 65, no. 3, p. 2,385-2,397, doi:10.1007/s11069-012-0407-y.

Detterman, R.L., Miller, T.P., Yount, M.E., and Wilson, F.H., 1981, Quaternary geologic map of the Chignik and Sutwik Island quadrangles, Alaska: U.S. Geological Survey Miscellaneous Investigations Series Map 1292, 1 sheet, scale 1:250,000.

Division of Community and Regional Affairs (DCRA) (State of Alaska), Alaska Community Database: Port Heiden, website last accessed March 2014, http://commerce.alaska.gov/cra/DCRAExternal/community.

Dolan, Robert, Fenster, M.S., and Holme, S.J., 1991, Temporal analysis of shoreline recession and accretion: Journal of Coastal Research, v. 7, no. 3, p. 723-744.

Ferrians, O.J., Jr., 1965, Permafrost map of Alaska: U.S. Geological Survey Miscellaneous Geologic Investigations Map 445, 1 sheet, scale 1:2,500,000.

Francis, O.P., Panteleev, G.G., and Atkinson, D.E., 2011, Ocean wave conditions in the Chukchi Sea from satellite and in situ observations: Geophysical Research Letters, v. 38, no. 24, doi:10.1029/2011GL049839.

Gould, A.I., and Kinsman, N.E.M., 2013, Spatially referenced oblique aerial imagery of the Port Heiden shoreline, August 2013: Alaska Division of Geological \& Geophysical Surveys Raw Data File 2013-10, 2 p., doi:10.14509/26866.

Hapke, C.J., and Reid, David, 2007, National assessment of shoreline change, part 4-Historical coastal cliff retreat along the California coast: U.S. Geological Survey Open-File Report 2007-1133, 51 p. 
Hartmann, Brian, and Wendler, Gerd, 2005, On the significance of the 1976 Pacific climate shift in the climatology of Alaska: Journal of Climate, v. 18, no. 22, p. 4,824-4,839.

Himmelstoss, E.A., 2009, DSAS 4.0 Installation instructions and user guide, in Thieler, E.R., Himmelstoss, E.A., Zichichi, J.L., and Ergul, Ayhan, Digital shoreline analysis system (DSAS) version 4.0-An ArcGIS extension for calculating shoreline change: U.S. Geological Survey Open-File Report 2008-1278, 79 p.

Historical Sea Ice Atlas (HSIA), University of Alaska, 2014, Interactive Map, website last accessed March 2014: http:// seaiceatlas.snap.uaf.edu/

Hogan, E.V., 1995, Overview of environmental and hydrogeologic conditions near Port Heiden, Alaska: U.S. Geological Survey Open-File Report 95-407, 7 p.

Horikawa, Kiyoshi, ed., 1988, Nearshore dynamics and coastal processes-Theory, measurement, and predictive models: Tokyo, University of Tokyo Press, 522 p.

Hunter, R.E., Sallenger, A.H., and Dupre, W.R., 1979, Maps showing directions of longshore sediment transport along the Alaskan Bering Sea coast: U.S. Geological Survey Miscellaneous Field Studies Map 1049, 7 p., 5 sheets, scale 1:400,000.

Iliaska Environmental LLC, 2008, Phase I environmental site assessment at the Meshik town site near Port Heiden, Alaska, $45 \mathrm{p}$.

Karl, T.R., Melillo, J.M., and Peterson, T.C., eds., 2009, Global climate change impacts in the United States-U.S. Global Change Research Program: Cambridge, NY, Cambridge University Press, 196 p., www.globalchange.gov/usimpacts.

Kinsman, N.E.M., and DeRaps, M.R., 2012, Coastal hazard field investigations in response to the November 2011 Bering Sea storm, Norton Sound, Alaska: Alaska Division of Geological \& Geophysical Surveys Report of Investigation 2012-2 v. 1.1, 51 p., 1 sheet, doi:10.14509/24484.

Kvasager, Darl W., 1975, Erosion study for Port Heiden, Alaska: Anchorage, Hewitt V. Lounsbury \& Associates, 14 p.

Legare, Harlan, 2000, Field trip to Port Heiden (memorandum): United States Army Corps of Engineers, Hydraulic and Hydrology Section, $11 \mathrm{p}$.

Mesquita, M.S., Atkinson, D.E., and Hodges, K.I., 2010, Characteristics and variability of storm tracks in the North Pacific, Bering Sea, and Alaska: Journal of Climate, v. 23, no. 2, p. 294-311.

Moore, L.J., 2000, Shoreline mapping techniques: Journal of Coastal Research, v. 16, no. 1, p. 111-124.

National Oceanic and Atmospheric Administration (NOAA), 2013, Tides \& Currents: Center for Operational Oceanographic Products and Services, website last accessed March 2014, www.noaa.gov/

NOAA, 2007, Port Heiden dump site: Incident News, website last visited March 2014, http://incidentnews.noaa. gov/incident $/ 7715$

2006, Alaska ShoreZone Coastal Mapping and Imagery (2006 collection), website last visited March 2014, https://alaskafisheries.noaa.gov/shorezone/

Pearce, N.J.G., Westgate, J.A., Preece, S.J., Eastwood, W.J., and Perkins, W.T., 2004, Identification of Aniakchak (Alaska) tephra in Greenland ice core challenges the 1645 BC date for Minoan eruption of Santorini: Geochemistry, Geophysics, Geosystems, v. 5, no. 3, doi:10.1029/2003GC000672.

Reger, R.D., Campbell, K.M., Stevens, D.S.P., and Smith, R.L., 2003, Survey of geology, geologic materials, and geologic hazards in proposed access corridors in the Chignik Quadrangle, Alaska: Alaska Division of Geological \& Geophysical Surveys Miscellaneous Publication 61, 5 sheets, scale 1:250,000, doi:10.14509/2942.

Ruggiero, Peter, Kratzmann, M.G., Himmelstoss, E.A., Reid, David, Allan, John, and Kaminsky, George, 2013, National assessment of shoreline change-Historical shoreline change along the Pacific Northwest coast: U.S. Geological Survey Open-File Report 2012-1007, 62 p., doi:10.3133/ofr20121007.

Sallenger, A.H., Jr., and Hunter, R.E., 1984, Maps showing the coastal morphology of the Bristol Bay coast of the Alaska Peninsula: U.S. Geological Survey Miscellaneous Field Studies Map 1672, 2 sheets, scale 1:400,000.

Schumacher, J.D., and Kinder, T.H., 1983, Low-frequency current regimes over the Bering Sea shelf: Journal of Physical Oceanography, v. 13, no. 4, p. 607-623.

Sea Level Research Group (SLRG), 2013, Regional sea level time series: University of Colorado, website last accessed March 2014: http://sealevel.colorado.edu/content/regional-sea-level-time-series

Stergiou, Elizabeth, 2013, Coastal impact assistance program waste erosion assessment and review trip report: Alaska Department of Environmental Conservation, 5 p., http://dec.alaska.gov/eh/sw/WEAR Reports.html

Sunamura, Tsuguo, 1992, Geomorphology of rocky coasts (vol. 3): New York, John Wiley \& Son Ltd., 302 p.

Thieler, E.R., Himmelstoss, E.A., Zichichi, J.L., and Ergul, Ayhan, 2009, The digital shoreline analysis system (DSAS) version 4.0-An ArcGIS extension for calculating shoreline change: U.S. Geological Survey Open-File Report 2008-1278, accessed March 19, 2014, at http://woodshole.er.usgs.gov/project-pages/dsas/version4/

United States Army Corps of Engineers (USACE), 2013, Flood hazard data for Alaska communities: Alaska District, Civil Works Floodplain Management, available online, http://www.poa.usace.army.mil/About/Offices/Engineering/FloodplainManagement.aspx 
USACE, 2012, Wave Information Studies, website last accessed March 2014: http://wis.usace.army.mil/hindcasts.shtml USACE, 2007, Alaska Baseline Erosion Assessment, Erosion Information Paper-Port Heiden Alaska, 4 p., accessed March 20, 2014, http://www.poa.usace.army.mil/Portals/34/docs/civilworks/BEA/Port\%20Heiden_Final\%20Report.pdf United State Census Bureau, 2010, Profile of general population and housing characteristics, 2010 demographic profile data, available online, http://factfinder2.census.gov/main.html

Wise, James L., Leslie, Lynn D., and Labelle, Joseph C., 1987, An oceanographic and climatological atlas of Bristol Bay: Washington, D.C., United States Coast Guard, Office of Engineering and Development, 193 p., available online, http:// www.dtic.mil/mwg-internal/de5fs23hu73ds/progress?id=jr9pNmC/o7

Wise, James L., Comiskey, Albert L., and Becker, Richard, 1981, Storm surge climatology and forecasting in Alaska: Anchorage, Alaska, Arctic Environmental Information and Data Center, University of Alaska, $32 \mathrm{p}$. 